\title{
The vegetation and climate during the Last Glacial Cold Period, northern South Island, New Zealand
}

\author{
S. Louise Callard ${ }^{\mathrm{a}, *}$, Rewi M. Newnham ${ }^{\mathrm{a}}$, Marcus J. Vandergoes ${ }^{\mathrm{b}}$, Brent V. Alloway ${ }^{\mathrm{a}}$, \\ Carol Smith ${ }^{c}$ \\ a School of Geography, Environment E' Earth Sciences, Victoria University of Wellington, New Zealand \\ ${ }^{\mathrm{b}}$ GNS Science, 1 Fairway Drive, Avalon, PO Box 30368, Lower Hutt, New Zealand \\ ${ }^{\mathrm{c}}$ Faculty of Agriculture and Life Sciences, Lincoln University, New Zealand
}

\section{A R T I C L E I N F O}

\section{Article history:}

Received 9 May 2012

Received in revised form

4 December 2012

Accepted 13 December 2012

Available online 26 January 2013

\section{Keywords:}

Palaeoenvironmental change

Pollen

Beetles

New Zealand

Last Glacial Cold Period (LGCP)

Glacial refugia

\begin{abstract}
A B S T R A C T
Pollen assemblages from Howard Valley, South Island, New Zealand, were used to reconstruct the palaeovegetation and infer past climate during the period ca 38-21 cal. ka, which encompasses the Marine Isotope Stage (MIS) 3/2 transition and Last Glacial Cold Period (LGCP). A glacier occupied the upper Howard Valley during the Last Glacial, whilst extensive glaciofluvial outwash surfaces were constructed in the lower valley. Episodic periods of fluvial aggradation and incision have produced a complex sequence of terraces flanking the main Howard River and its tributaries. Sedimentary sequences from three exposed valley fills, sampled for palynological analysis and radiocarbon dating, consist of a complex vertical and lateral arrangement of coarse textured cobbly sandy gravels interbedded with organic-rich silt deposits. Palynology of these organic-rich horizons was directly compared to an existing beetle record from these same horizons. During late MIS 3 the site was dominated by marshy shrubland vegetation interspersed with mixed beech forest, indicating temperatures $\sim 2-3{ }^{\circ} \mathrm{C}$ cooler than present. Climate cooling began as early as 35.7 cal. ka and coincides with evidence of cooling from other sites in New Zealand, South America and with an Antarctic cooling signature. A three phase vegetation and inferred climate pattern occurs at the site during the LGCP beginning with a transition to an alpine/sub-alpine grassland comparable to communities growing near treeline today marking the change to glacial conditions before $31 \mathrm{cal}$. ka. A small increase in tree abundance between ca 25.8 and 22.7 cal. ka suggests minor climate amelioration during the mid-LGCP. During this phase, a possible volcanically induced vegetation disruption caused by the deposition of the Kawakawa Tephra at $25 \mathrm{cal}$. ka is evident in the pollen record. This is followed by a further decline in tree pollen and increase in alpine grassland and herb pollen indicating further deterioration of conditions and a period of maximum cooling $\left(\sim 4.5^{\circ} \mathrm{C}\right)$ ca $22.5-20.9$ cal. ka. This corresponds with the timing of greatest ice advance based on the geomorphic evidence in the region. Contrary to previous studies in New Zealand, the pollen and beetle records are in close agreement. Both indicate the site was forested during late MIS 3 , with progressive reduction of trees during the LGCP. The consistent presence of beech pollen nevertheless confirms small refugia of trees persisted in the region.
\end{abstract}

(c) 2013 Elsevier Ltd. All rights reserved.

\section{Introduction}

The northern South Island has been a focus of recent discussion concerning forest refugia in New Zealand during the Last Glacial Coldest Period (LGCP) defined here as the period spanning 28-18 cal. ka (Alloway et al., 2007). This is particularly the case towards the end of the LGCP (Marra and Leschen, 2004; Burge and Shulmeister, 2007; McGlone et al., 2010; Newnham et al., 2013).

\footnotetext{
* Corresponding author. Tel.: +44 188438905.

E-mail address: callardsl1@gmail.com (S.L. Callard).
}

Central to this discussion are the composition and extent of forest survival in the region inferred from beetle and pollen records. Wider interest in this discussion stems from alternative views of glacial forest refugia in regions such as northwest Europe, where the traditional assumption of complete forest elimination from middle and high latitudes during glacials has recently come under challenge from the 'cryptic-' or 'micro-' refugia hypothesis (Stewart and Lister, 2001; Provan and Bennett, 2008; Kelly et al., 2010). In New Zealand, pollen and plant macrofossil evidence have favoured the concept of cryptic glacial forest refugia (McGlone, 1985; Newnham et al., 2013), but beetle evidence has 
recently been used to argue for more extensive forest survival during the LGCP, and for milder climates than previously elucidated from pollen records (Burge and Shulmeister, 2007).

The Howard Valley site in the Nelson Lakes District of northern South Island is critical to this discussion. A fragmentary beetle and plant macrofossil record from this site provided evidence of vegetation during late Marine Isotope Stage (MIS) 3 and 2 (Marra and Thackray, 2010), a period containing few palaeovegetation records. These proxies indicated that the site was forested during late MIS 3 and that forest refugia may have persisted during the LGCP. In this paper we present new pollen records from the same three sections at Howard Valley sampled by Marra and Thackray (2010) to provide further evidence of vegetation and climate change for MIS 3 and 2. We have extended the stratigraphic descriptions and sampling both vertically and laterally and have undertaken further radiocarbon dating to provide a higher resolution palaeovegetation record. The pollen record builds upon, and allows comparison with, the existing palaeoenvironmental evidence at the site. Estimates of temperature depression before and during the LGCP are also provided.

\section{Regional description}

Howard Valley is located in southeast Nelson, within the Nelson Lakes district, at the northern limit of the Southern Alps (Fig. 1). The Howard River is a tributary of the Buller River, which drains Lake Rotoiti and flows westwards to the Tasman Sea at Westport. Nelson Lakes District is an upland region where mountain ranges reach $2000 \mathrm{~m}$ above sea level (a.s.l) with valleys typically between 1200 and $500 \mathrm{~m}$ a.s.l. The region experiences a cool-temperate climate with mean annual temperature of $9{ }^{\circ} \mathrm{C}$ and mean summer and winter temperatures of $14{ }^{\circ} \mathrm{C}$ and $4{ }^{\circ} \mathrm{C}$, respectively (recorded at Lake Rotoiti weather station; New Zealand National Climate Centre, 2010). The prevailing wind is from the northwest, bringing
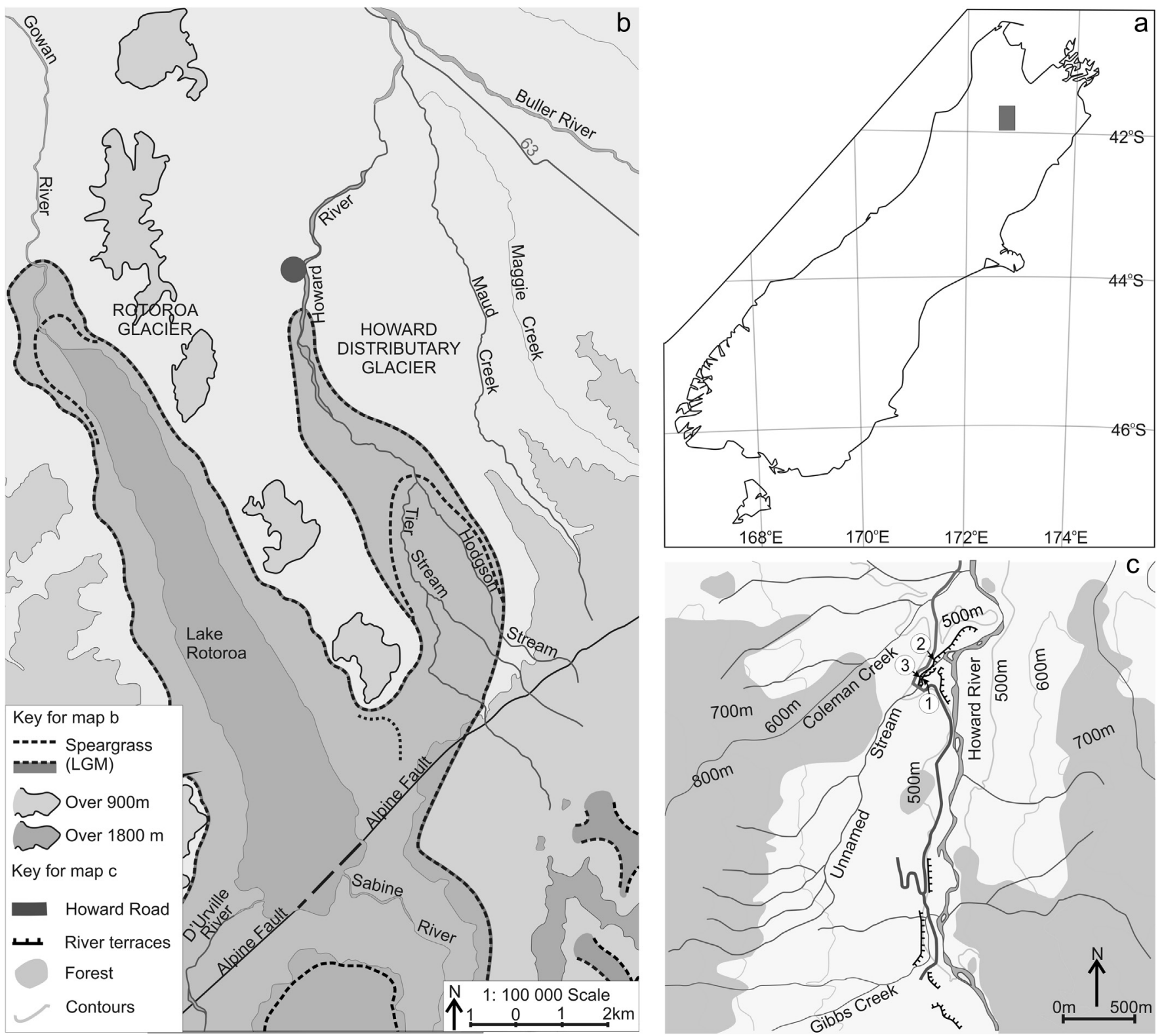

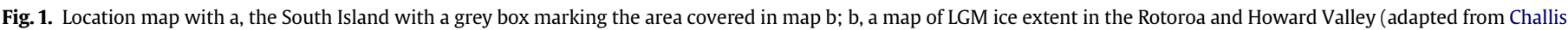
et al., 1994) and grey circle marking the sample sites; c, a detailed map of the study sites in Howard River and tributary stream. 
moisture laden air masses resulting in high mean annual precipitation of $1600 \mathrm{~mm}$, falling evenly throughout the year.

The modern vegetation of lowland and flat lying areas has been heavily modified by human activity with large areas deforested for agriculture. The remaining native vegetation is restricted to upland areas and steep mountain sides. Below the treeline, beech (Nothofagus) forest dominates with Nothofagus fusca dominant up to $900 \mathrm{~m}$ a.s.l, Nothofagus menziesii up to $1100 \mathrm{~m}$ a.s.l and Nothofagus solandri var. cliffortiodes to the treeline at $1400 \mathrm{~m}$ a.s.l. The treeline is characterised by a sharp transition from $N$. solandri var. cliffortiodes sub-alpine forest to Chionochloa grassland. Patches of shrubland comprising Phyllocladus alpinus, Hebe/Veronica, Coprosma, Dracophyllum uniflorum, D. pronum and Podocarpus nivalis grow at this transition point (Wardle, 1965). Alpine vegetation, based upon a pollen rain study by Moar (1970) from a site between Lake Rotoroa and Lake Rotoiti at $1700 \mathrm{~m}$ a.s.l, includes Asteraceae (incl. Abrotanella sp, Celmisia sessiliflora and Craspedia uniflora), Anistome aromatica (Apiaceae), Coprosma pumila, Gaultheria depressa and Poaceae (incl. Chiononchlea australis, C. pallens and Hierochloe).

At times, throughout the Quaternary, southeast Nelson region was extensively glaciated with glaciers flowing down the St Arnaud and Spencer Mountain ranges into the Rotoroa and Rotoiti valleys (Suggate, 1965). The ice extent is marked by numerous terminal moraines which have been mapped and described (Suggate, 1965; McCaplin, 1992a, 1992b; Shulmeister et al., 2005). A glacier, known as the Howard Valley distributary glacier, spilled over a small divide at the southern end of Rotoroa Valley, between Mt Cedric and the Muntz Range, into the Howard Valley. During earlier glacial events this glacier occupied the entire Howard Valley and flowed into the Buller Valley, however, during the LGCP it was restricted to the upper valley and the mid and lower sections remained ice free (Fig. 1). Extensive outwash aggradation deposits of the Speargrass formation (Suggate, 1965), were sourced from small cirques and the main valley glacier at the head of the Howard Valley. The Speargrass formation has been correlated to the Larrikins formation located in north Westland region. Two ice advances associated to the Larrikins formation occurred between ca 34-28 cal. ka and ca 24.521.5 cal. ka. A third advance, known as the Moana in North Westland occurred between ca 20.5 and 19 cal. ka (Suggate and Almond, 2005). Episodic aggradation followed by incision has produced a flight of aggradation and degradation terraces that flank both sides of the main Howard River and its tributaries. Sediment flux within the tributaries that control the formation of these terraces is complicated, and appears to be a function of not only climaterelated palaeoenvironmental changes but also the occurrence of numerous intravalley bedrock obstacles that constrict the passage of sediment down valley forming sediment reservoirs (Suggate, 1988; Challis et al., 1994).

\subsection{Study site}

The middle section of the Howard Valley and its tributaries contain flights of low river terraces reaching $30 \mathrm{~m}$ above the current valley floor. Three exposures of valley fills on terrace edges were sampled and labelled $1-3$ in age order, with 1 being the youngest. The sections sampled are the same sections analysed for beetle and plant macrofossils by Marra and Thackray (2010) and occur at an altitude of ca $476 \mathrm{~m}$ a.s.l. Sections 1 and 3 are located up an unnamed tributary to the Howard River $\left(41^{\circ} 46^{\prime} 38^{\prime \prime} S\right.$, $171^{\circ} 39^{\prime} 36^{\prime \prime} \mathrm{E}$ ) (Figs. 1 and 4). The lower section of this unnamed tributary contains a flight of at least 7 terraces at varied heights that do not obviously pair across the valley. Section 1, the youngest deposit, aged between 22.7 and $20.9 \mathrm{cal}$. ka, is exposed on the south-eastern bank of the unnamed tributary. Section 3, the oldest deposit (37.7-29.2 cal. ka) is located $30 \mathrm{~m}$ across the valley from

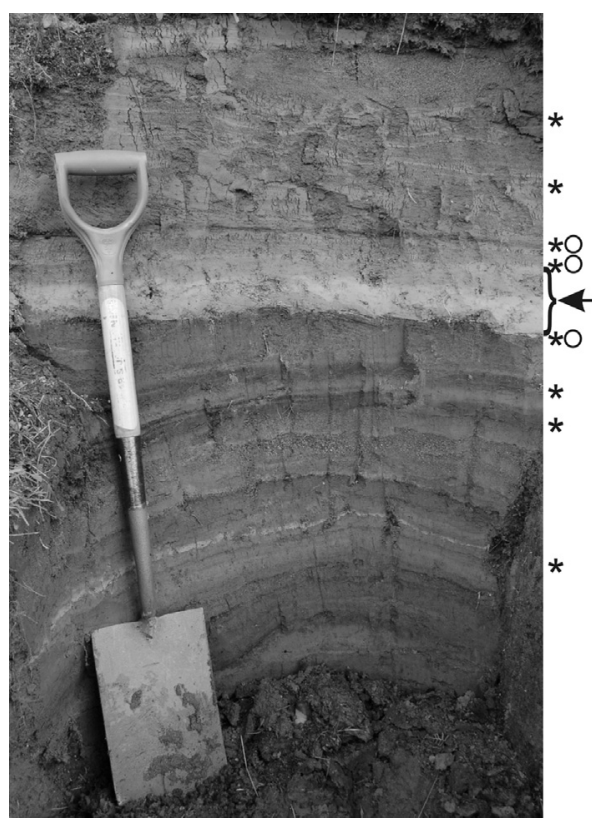

Fig. 2. Kawakawa Tephra (indicated by arrow) as observed in Section 2 enveloped in organic-rich silt and sands. The asterisks mark the position of samples taken for pollen analysis. The open circles mark the position of samples taken for phytolith analysis. The spade is $1 \mathrm{~m}$ length (Photo-BV Alloway).

Section 1. A core was taken from the base of the section, extending it by $69 \mathrm{~cm}$ relative to the lowermost horizons sampled by Marra and Thackray (2010).

Section 2 is located $200 \mathrm{~m}$ downstream from Sections 1 and 3 in the main Howard River Valley $\left(41^{\circ} 46^{\prime} 38^{\prime \prime} \mathrm{S}, 171^{\circ} 39^{\prime} 43^{\prime \prime} \mathrm{E}\right.$; Figs. 1 and 4) and is of intermediate age, spanning 26.2-21.9 cal. ka. This section includes a ca $10 \mathrm{~cm}$ thick volcanic ash layer, previously identified at this site as Kawakawa Tephra (Campbell, 1986). The stratigraphy for Section 2 was significantly extended up and down compared to the study by Marra and Thackray (2010) who only sampled the organic material bounding the Kawakawa Tephra layer. For this study a core was taken at the base of the section and the whole terrace exposure was cleared of adhering vegetation so that other organic-rich interbeds could be sampled.

\subsection{Previous work}

The record of LGCP vegetation from southeast Nelson is mostly derived from fragmentary pollen records from river terraces. Howard Valley has long been recognised as a particularly important site in the region because of the occurrence of Kawakawa Tephra as a prominent layer interbedded with organic-rich silt (Campbell, 1986). Palynology of the organic layers immediately above and below the tephra layer by Moar in Suggate (1988) and McLea (1996) showed that the regional vegetation was dominated by alpine grass and herbland, containing low abundance of woody shrubs including Phyllocladus. Cyperaceae pollen was abundant, indicating a swampy local depositional environment. The presence of pollen of Fuscopora (previously termed $N$. fusca type) podocarp/broadleaved trees and $N$. menziesii in trace amounts at this and nearby sites suggested that the region may have supported forest refugia during the LGCP (Moar, 1971, 1980; Mabin, 1983; McLea, 1996). Subsequently, Moar et al. (2008) reported high Nothofagus LGCP pollen levels (ca 80\%) at a coastal site from north Westland, ca $65 \mathrm{~km}$ northwest of Howard Valley, consistent with the persistence of closed canopy forest. This coastal locality contrasts with the dominance of herbaceous taxa at most other inland sites from this 

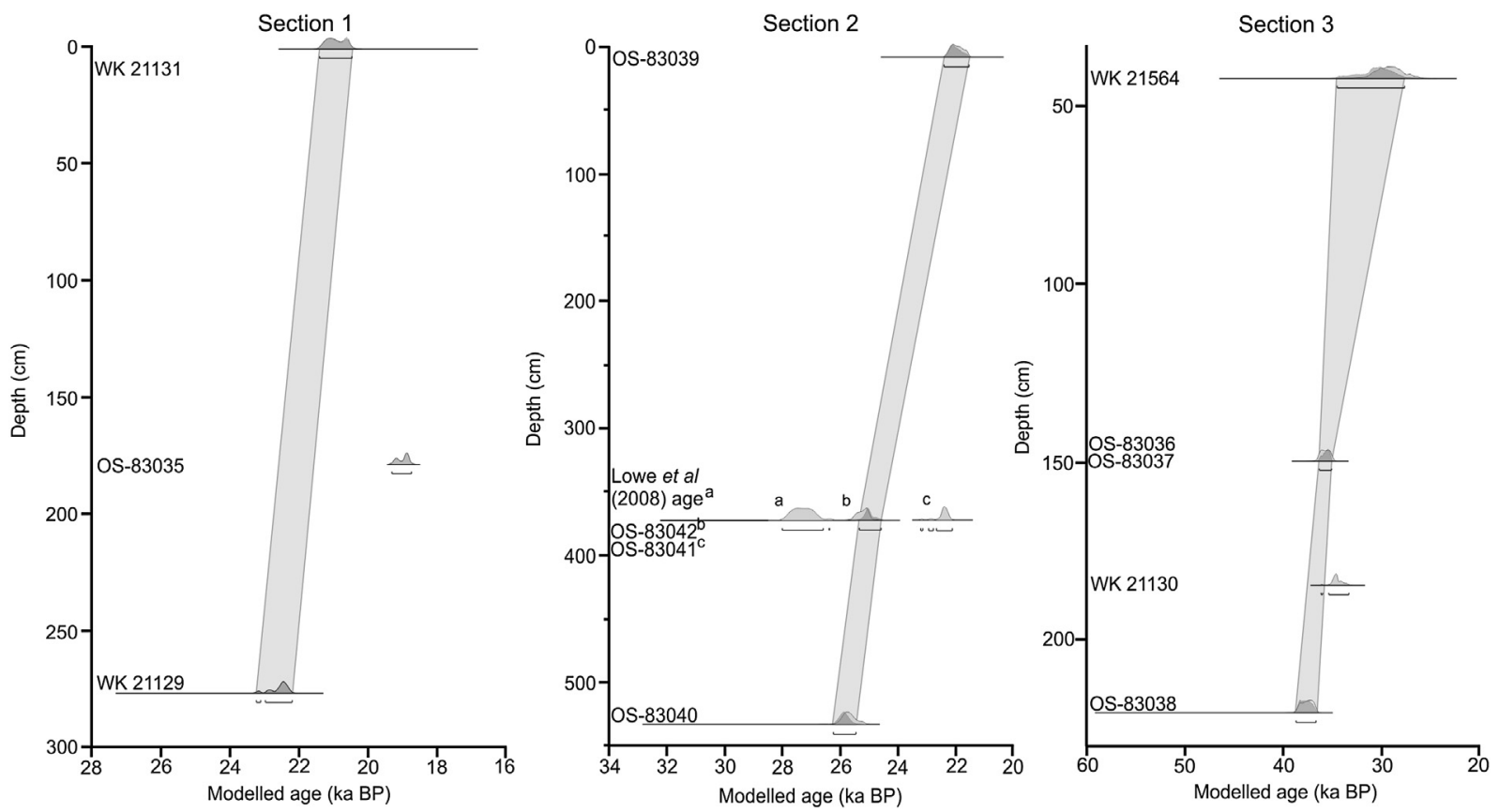

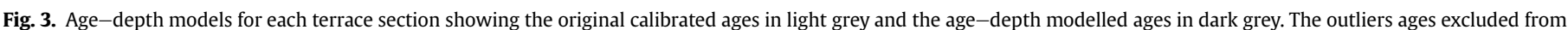
the age-depth model are including in the figure.

region. More recently, Marra and Thackray (2010), expanded on the fragmentary vegetation record at Howard Valley, using beetle and plant macrofossil evidence preserved at the site. The stratigraphy of two adjacent valley fills was included to extend the overall record so it spanned from late MIS 3-18.9 cal. ka. Marra and Thackray (2010) concluded that the site contained $N$. menziesii beech forest during MIS 3 based on an abundance of $N$. menziesii leaves in the plant macrofossil record and beetle taxa associated with $N$. menziesii forest habitats. Around the time of deposition of Kawakawa Tephra, the site was at or near the treeline limit whilst at other times during the LGCP grass and herb taxa dominated and there is little evidence of forest. The palaeovegetation records suggest the LGCP was considerably colder than at present, as inferred from the low abundance of beech pollen and macrofossil.

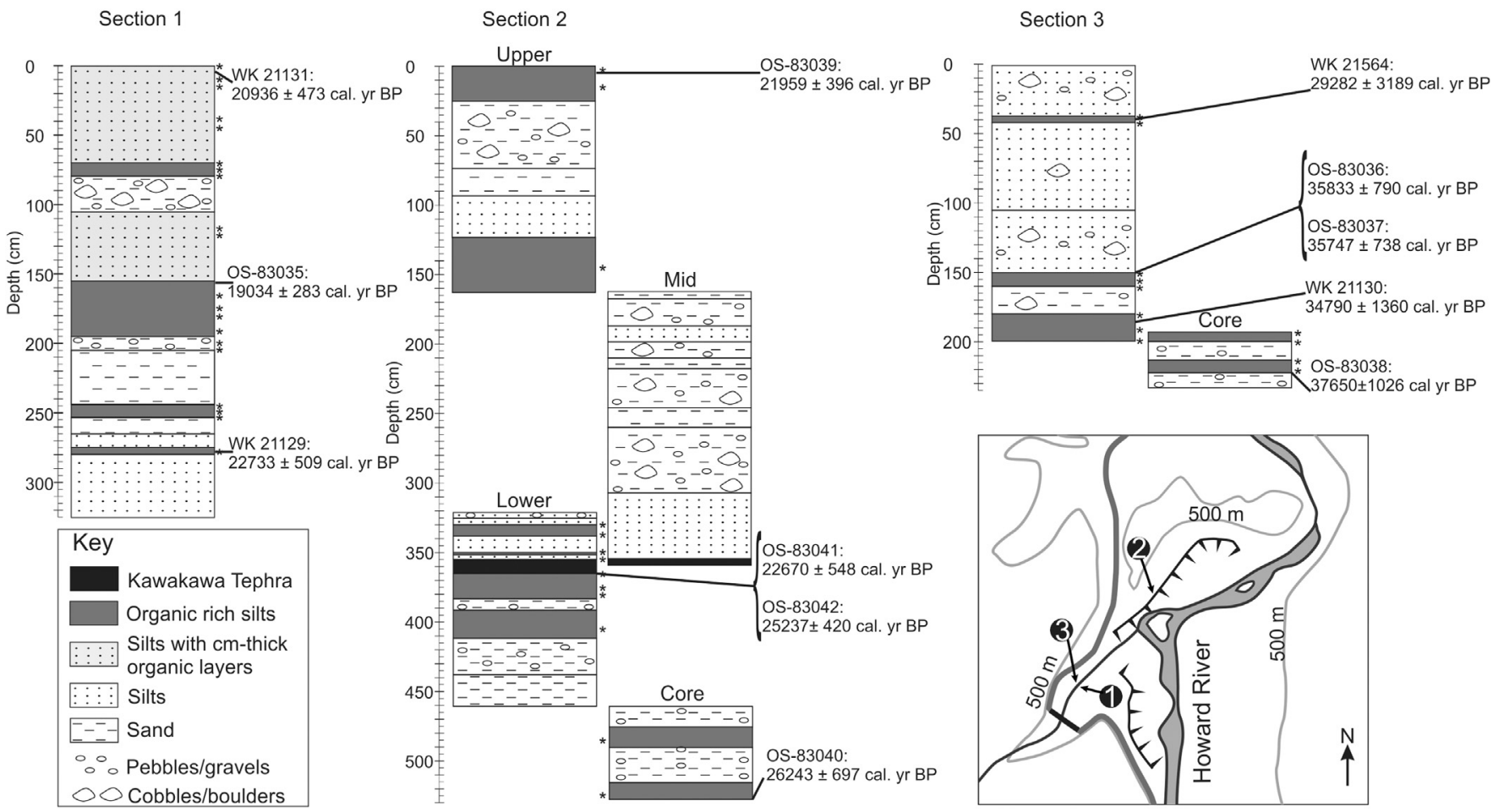

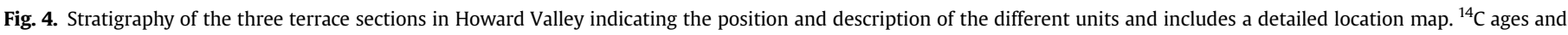
their unmodelled calibrated equivalents are located to the right hand side of each stratigraphy. The asterisks mark the pollen sample locations. 
During MIS 3 the climate was milder than during the LGCP, consistent with a lack of evidence of glaciation in the landscape for this time period.

The current study extends the previous work by presenting a longer and higher definition reconstruction of vegetation and climate with a radiocarbon-based chronology spanning the interval ca 38-21 ka. Expanding upon previous pollen and beetle analyses at the site is important in light of recent divergent interpretations of the extent of glacial forest refugia in New Zealand from these two proxies (McGlone et al., 2010).

\section{Methods}

\subsection{Field methods}

Three exposed valley fills where described and sampled in February 2008 and January 2009. In 2008 the organic bands were subsampled at $1 \mathrm{~cm}$ resolution for pollen analysis. Samples were cut directly from the section face at the same horizons previously sampled by Marra and Thackray (2010). In 2009, monoliths were collected from the thickest section (Section 2) and two cores were collected from the base of Sections 2 and 3 with an $8 \mathrm{~cm}$ diameter Livingston Piston corer. Coring at the base of Section 2 and 3 stopped when coarse-grained fluvial sediments obstructed progress. Prior to subsampling in the laboratory, the cores and monoliths were split in two and one half kept as an archive. The samples were logged, photographed and subsampled.

\subsection{Palynology}

A variable sample interval approach was used to provide appropriate palynological representation of the organic units in the three sections and to correspond with the sampled locations of Marra and Thackray (2010). Pollen preparation followed the standard laboratory procedure (10\% hot $\mathrm{KOH}, 40 \% \mathrm{HF}$ and acetolysis) outlined in Moore et al. (1991) using a sample size of $0.5 \mathrm{~cm}^{3}$. Each sample was spiked with exotic Lycopodium marker tablets to allow the calculation of pollen concentrations. The grains were stained by using aqueous safrinin and mounted in silicon oil. Slides were counted under a light microscope at $\times 400$ magnification, with $\times 1000$ oil immersion used on difficult grains. Pollen identifications were made with reference to the New Zealand pollen collections held at Victoria University of Wellington (VUW) and at Landcare Research, Lincoln, New Zealand, and standard texts (e.g. Pocknall, 1981; Large and Braggins, 1991; Moar, 1993). Pollen taxon abundances are expressed as percentages of a 250 grain minimum pollen sum for each sample. The pollen sum includes all dryland taxa, but excludes tree ferns, pteridophytes and the shrub taxon Leptospermum as it is an important local wetland component. The term Fuscospora refers to all New Zealand Nothofagus species with the exception of $N$. menziesii. Poaceae pollen grains spanned a wide range of sizes and are split into the large Chionochloa grains ( $>40 \mu \mathrm{m}$ diam) and the smaller grains ( $<40 \mu \mathrm{m}$ diam) characteristic of the short tussock grassland (McGlone and Moar, 1998). The program TILIA $v$ 1.7.16 was used to produce the pollen diagrams (Figs 6 and S1) and perform stratigraphically constrained cluster analysis using CONISS. The cluster analysis was performed on the dryland pollen types only. Squared root transformation using Edwards and Carvali-Sforza's chord distance was applied to the dataset to downweight the abundant taxa. Conventionally, stratigraphically constrained cluster analysis is applied to depth data. However, due to the fragmentary nature of the Howard Valley record depth is replaced by age and thereby a chronostratigraphically constrained cluster analysis is produced. A dendrogram is used to zone the pollen record.

\subsection{Biogenic silica}

Samples of sediment (10 g) for phytolith analysis were taken from three units, using a variable sample interval approach. These were the constraining units; one unit immediately below the Kawakawa Tephra (peat $8-10 \mathrm{~cm}$ thick) and two units immediately above (grey silt $2-3 \mathrm{~cm}$ thick) and a peat layer $(1-2 \mathrm{~cm}$ thick) which was immediately overlying the grey silt unit. Phytolith extraction followed the method of Hughes (2008). Samples were treated to remove oxides and organic matter and were then wet sieved $(<250 \mu \mathrm{m})$. Clay was removed by careful dispersion and supernatant removal. Sodium polytungstate (density $2.35 \mathrm{~g} \mathrm{~cm}^{-3}$ ) was mixed with the sample and centrifuged at $1000 \mathrm{rpm}$ for $10 \mathrm{~min}$ followed by removal of material (density $\leq 2.35 \mathrm{~g} \mathrm{~cm}^{-3}$ ) by pipette. An aliquot was placed on a microscope slide, dried under a heat lamp and mounted with coverslips using Canada Balsam. Resolution of phytoliths was good, facilitating morphotype identification.

Minimum counts of 300 biogenic silica bodies (comprising phytoliths and diatoms) were made for each slide and phytoliths were classified into one of 16 morphotypes (Piperno, 1988; Kondo et al., 1994; Carter, 2000; Carter and Lian, 2000). Phytoliths were counted using an Olympus 53XP polarising microscope, under plane polarised light at $\times 100$ magnification. Phytolith abundance was expressed as a percentage of the biogenic silica count. Phytolith taxonomy continues to evolve (Piperno, 1988; Carter and Lian, 2000; Thorn, 2004a, 2004b; Lu et al., 2006) and international codes for nomenclature are being developed (Madella et al., 2005). For this study, the morphotypes were classified according to the schemes developed and used in New Zealand (Kondo et al., 1994; Carter and Lian, 2000; Prebble and Shulmeister, 2002). The methods used to extract phytoliths also extracted fragmented soil diatom tests; these were counted and expressed as percentages of the overall biogenic silica count. Diatoms were identified using NIWA resources (http://www.niwa.co.nz/rc/prog/freshdiversity/diatom).

\subsection{Environmental Lapse Rates}

We attempted to use the recently developed transfer function method (Wilmshurst et al., 2007) to quantify past temperature change from the Howard Valley pollen spectra but the results were considered unreliable due it seems to a lack of modern analogues in the calibration dataset (Newnham et al., 2013). Instead, we have used the Environmental Lapse Rate (ELR), the rate at which temperature changes with altitude (Meyer, 1992), to estimate MAT depression for the site based upon the elevational lowering of vegetation zones inferred from the palaeovegetation record. This was achieved for a given pollen assemblage by applying an ELR of $0.5^{\circ} \mathrm{C} / 100 \mathrm{~m}$ to the difference in elevation between the site (476 m a.s.l) and the contemporary elevation of vegetation communities inferred from the pollen assemblage. The ELR is a mean annual rate calculated from data of 301 New Zealand climate stations spanning 1950-1980 AD (Norton, 1985). There are limitations with this approach. ELRs are a semi-qualitative method relying on interpretation of the palaeovegetation community. Also, a number of factors associated with both temporal and spatial changes can modify the ELR calculated including changing atmospheric conditions (although over long timescales these are assumed to average out), the surface albedo, moisture, local and regional topography, the time of day, and the nature and source of the dominant air mass to name a few (Meyer, 1992). The estimated MAT depressions should be treated as approximations.

\subsection{Radiocarbon dating}

Radiocarbon dating provides the main chronological control for this study. Samples were submitted to the Rafter Radiocarbon 
Laboratory of GNS Science (NZ) for analysis by accelerator mass spectrometry (AMS) (see Table 1). Bulk sediment, plant macrofossils and wood were used for dating. In addition, we use the ${ }^{14} \mathrm{C}$ ages reported by Marra and Thackray (2010) where appropriate.

Age-depth relationships were derived with the Bayesian calibration program OxCal (version 4.1.7; Ramsey, 2009). The objective was to evaluate the viability of the ${ }^{14} \mathrm{C}$ ages obtained and to provide a basis for extrapolating between the dated horizons to further points of interest in the pollen records. Outlier analysis provided the options of either downweighting suspect ages or removing significant outliers and rerunning the model. The IntCal09 calibration curve was applied to the entire dataset (Reimer et al., 2009; Table 1) including recalibration of the radiocarbon ages of Marra and Thackray (2010). See supplementary information for a detailed age-depth model methodology.

\subsection{Kawakawa Tephra}

The major element composition of glass shards as determined by electron microprobe analysis confirms the identification of the $10 \mathrm{~cm}$ thick tephra layer in Section 2 (Fig. 2) as Kawakawa Tephra (Table 2). The current reported age of Kawakawa Tephra is ca $27.3 \pm 0.7$ cal. ka (95\% probability; IntCal09; Lowe et al., 2008). However, a recently refined age of ca $25.4 \pm 0.2$ cal. ka (95\% probability, IntCal09), a centred calendar age $\sim 2000$ yrs younger than the reported age has been put forward (Vandergoes et al., 2013). The age of the tephra used in this study will be discussed further in Section 4.2 in relation to the Howard Valley chronology.

\section{Results}

\subsection{Chronology}

\subsubsection{Section 3}

The chronology for Section 3 is developed from five ages, including two from Marra and Thackray (2010) and spans the period $37.7 \pm 1-29.2 \pm 3.2$ cal. ka. The chronology contains an age reversal at $180 \mathrm{~cm}$, sample WK 21130 , which is $\sim 1300$ yrs younger than both samples OS-83036 and OS-83037 at $150 \mathrm{~cm}$. The ages from OS-83036 and OS-83037 are derived from wood and the bark encasing the wood, whilst WK 21130 is dated from a bulk sediment sample, likely to be more susceptible to contamination by older or younger carbon (Brown et al., 1989). Outlier analysis indicates WK 21130 was a significant outlier in the sequence and therefore it was removed from the chronology.
WK 21564 dates the top organic layer of the section. This age is considerably younger than the underlying dated organic horizon and suggests only $100 \mathrm{~cm}$ of sediment accumulated over 6000 years. This appears to be a relatively low sediment accumulation rate, especially when comparisons are made to the youngest section, located on the opposite bank, which accumulated $270 \mathrm{~cm}$ over only 1000 years. Although contamination of the younger sample is a possibility, the large age gap may be explained by river cut and fill processes, whereby the older material was eroded away followed by aggradation of younger material. Evidence of stream erosion followed by aggradation is visible throughout the other sections.

\subsubsection{Section 2}

The chronology for Section 2 relies on four radiocarbon ages and the age of Kawakawa Tephra. The ages lie in stratigraphic order spanning 26.2-21.9 ka. However, the two ages used to date the Kawakawa Tephra, OS-83041 and OS-83042, have a difference in mean calendar age of 3000 yrs, and both ages are significantly younger than the accepted Kawakawa Tephra age (Lowe et al., 2008). Outlier analysis of the chronology suggests that both the accepted Kawakawa Tephra age and OS-83041 are outliers in the chronology of this section (Fig. 3). We note that the modelled age for the tephra layer more closely aligns with a revised age by Vandergoes et al. (2013).

\subsubsection{Section 1}

The chronology of Section 1 is made from three ages, including two from Marra and Thackray (2010), and spans the period $22.7 \pm 0.5$ cal. ka to $20.9 \pm 0.5 \mathrm{cal}$. ka. The section contains a significant age reversal in the middle that was resolved when sample OS-83035 was removed from the chronology after outlier analysis. There is no evidence of cut and fill processes in this part of Section 1 , therefore the likely cause of this age-reversal is from contamination. The chronology of this section suggests stratigraphic overlap with the top of Section 2. Recalibration of the Marra and Thackray (2010) ages using IntCal09 produces calendar ages $\sim 2$ ka older than originally published, more than what can be explained by differences between the IntCal04 and IntCal09 calibrations. A simple explanation for this is an error in the format the ages were written in the original publications, which may have been mistakenly written as yrs BP when there are actually yrs BC. This age difference should be considered when making comparisons between the two records.

\subsubsection{Modelled chronology}

Age-depth models developed for each section (Fig. 3) show, in most cases, modelled ages similar to the original calibrated ages

Table 1

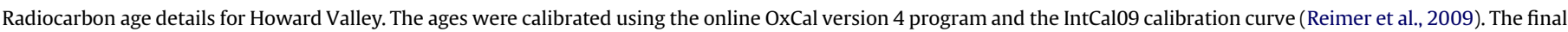

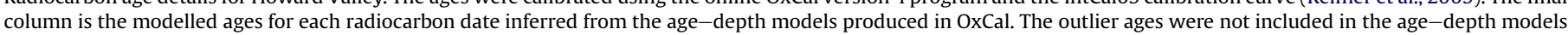
and remain unmodelled. * Ages produced by Marra and Thackray (2010), ** Ages produced by Vandergoes et al. (2013).

\begin{tabular}{|c|c|c|c|c|c|c|c|}
\hline Sample & $\begin{array}{l}\text { Section } \\
\text { (depth } \mathrm{cm} \text { ) }\end{array}$ & Fraction & ${ }^{14} \mathrm{C}$ age $\mathrm{BP}$ & $\Delta^{13} \mathrm{C} \%$ & $\begin{array}{l}\text { Reference } \\
\text { code }\end{array}$ & $\begin{array}{l}\text { Calibrated } \\
\text { age BP }(2 \sigma)\end{array}$ & $\begin{array}{l}\text { Modelled } \\
\text { age BP }(2 \sigma)\end{array}$ \\
\hline *How 1-7 & $1(0-1)$ & Peat & $17586 \pm 133$ & -28.5 & WK 21131 & $20930 \pm 465$ & $20936 \pm 473$ \\
\hline HV1-179 & $1(178-179)$ & $>125 \mu \mathrm{m}$ & $15800 \pm 60$ & -28.6 & OS-83035 & $19034 \pm 283$ & $\mathrm{~N} / \mathrm{A}$ \\
\hline *How 1-1 & $1(278-279)$ & Peat & $18902 \pm 106$ & -30.7 & WK 21129 & $22733 \pm 509$ & $22729 \pm 517$ \\
\hline HV3-M3-8-9 & $2(8-9)$ & $>125 \mu \mathrm{m}$ & $18400 \pm 90$ & -23.67 & OS-83039 & $21917 \pm 374$ & $21964 \pm 386$ \\
\hline${ }^{* *} \mathrm{H} 3 \mathrm{~B}-3-1$ & $2(365-366)$ & Plant/wood & $18800 \pm 100$ & -22.45 & OS-83041 & $22670 \pm 548$ & $\mathrm{~N} / \mathrm{A}$ \\
\hline **H3B-3-2 & $2(365-366)$ & Plant/wood & $21100 \pm 110$ & -22.44 & OS-83042 & $25237 \pm 420$ & $24937 \pm 379$ \\
\hline HV3-core1-68-69 & $2(527-528)$ & $125-63 \mu \mathrm{m}$ & $21500 \pm 120$ & -28.31 & OS-83040 & $26243 \pm 697$ & $25869 \pm 412$ \\
\hline *How 3-3 & $3(42-43)$ & Peat & $24349 \pm 1393$ & -31.2 & WK 21564 & $29282 \pm 3189$ & $31112 \pm 3460$ \\
\hline HV2-150 & $3(150-151)$ & Wood & $31400 \pm 400$ & -24.8 & OS-83036 & $35833 \pm 790$ & $35727 \pm 662$ \\
\hline HV2-150 & $3(150-151)$ & Wood & $31200 \pm 350$ & -26.27 & OS-83037 & $35747 \pm 738$ & $35727 \pm 662$ \\
\hline *How 3-1 & $3(198-199)$ & Peat & $30004 \pm 433$ & -30.1 & WK 21130 & $34790 \pm 1360$ & $\mathrm{~N} / \mathrm{A}$ \\
\hline HV2-core1-28-29 & $3(221-222)$ & Wood & $32900 \pm 450$ & -25.31 & OS-83038 & $37650 \pm 1026$ & $37731 \pm 1024$ \\
\hline
\end{tabular}


Table 2

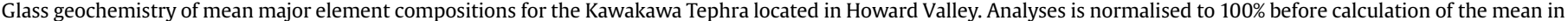

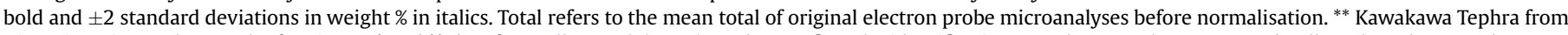

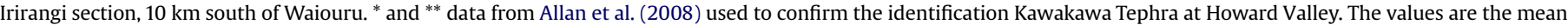
total of $n$ samples.

\begin{tabular}{|c|c|c|c|c|c|c|c|c|c|c|}
\hline Site and site code & $\mathrm{SiO}_{2}$ & $\mathrm{TiO}_{2}$ & $\mathrm{Al}_{2} \mathrm{O}_{3}$ & $\mathrm{FeO}$ & $\mathrm{MgO}$ & $\mathrm{CaO}$ & $\mathrm{Na}_{2} \mathrm{O}$ & $\mathrm{K}_{2} \mathrm{O}$ & $\mathrm{Cl}$ & Total \\
\hline Howard Valley & 77.4 & 0.19 & 12.6 & 1.25 & 0.14 & 1.03 & 4.03 & 3.15 & 0.22 & 95.43 \\
\hline H3/5/37-38 $(n=19)$ & 0.76 & 0.12 & 0.46 & 0.22 & 0.07 & 0.25 & 0.27 & 0.43 & 0.06 & 4.42 \\
\hline Howard Valley & 77.3 & 0.17 & 12.7 & 1.21 & 0.14 & 1.09 & 4.16 & 3.09 & 0.21 & 94.52 \\
\hline Н3/6/40-41 $(n=19)$ & 0.33 & 0.11 & 0.19 & 0.18 & 0.04 & 0.15 & 0.28 & 0.31 & 0.06 & 1.46 \\
\hline Howard Valley & 77.6 & 0.14 & 12.6 & 1.19 & 0.14 & 1.03 & 4.05 & 3.07 & 0.22 & 94.33 \\
\hline $\mathrm{H} 3 / 7 / 43-33(n=19)$ & 0.45 & 0.07 & 0.27 & 0.22 & 0.05 & 0.17 & 0.20 & 0.29 & 0.09 & 2.90 \\
\hline AT-331 & 77.4 & 0.15 & 12.6 & 1.19 & 0.14 & 1.08 & 4.06 & 3.08 & 0.21 & 94.71 \\
\hline$(\mathrm{ODP} \text { site } 1123)^{*}(n=64)$ & 0.84 & 0.07 & 0.45 & 0.25 & 0.05 & 0.17 & 0.50 & 0.33 & 0.08 & 3.98 \\
\hline \multirow[t]{2}{*}{ Kawakawa Tephra** $(n=24)$} & 77.2 & 0.16 & 12.8 & 1.25 & 0.14 & 1.10 & 4.06 & 2.97 & 0.20 & 94.98 \\
\hline & 1.04 & 0.11 & 0.77 & 0.18 & 0.06 & 0.22 & 0.38 & 0.27 & 0.06 & 2.29 \\
\hline
\end{tabular}

and all the modelled ages can account for $80 \%$ of the original age distribution. However, a 1.2 ka age difference occurs between the original calibrated age and modelled age for WK 21564. We attribute this problem to volatile fluctuations in sediment accumulation rate that have not been adequately captured in the model, which serves to illustrate the need to treat the age models with caution.

\subsection{Stratigraphy}

\subsubsection{Section 3}

Section 3 consists of $<2 \mathrm{~m}$ high exposure augmented by a $60 \mathrm{~cm}$ long core (Fig. 4). The core principally consists of unsorted coarse grey silty sands containing gravels ranging $2-5 \mathrm{~cm}$ in diameter. A $6.5 \mathrm{~cm}$-thick organic-rich sandy silt (aged $37.7 \pm 1$ cal. ka) interrupts the sequence at $222 \mathrm{~cm}$ and forms a sharp contact with the overlying inorganic material. The top $6 \mathrm{~cm}$ of the core also consists of dark brown organic-rich silt and overlaps the exposure base that starts at $199 \mathrm{~cm}$. The bottom $49 \mathrm{~cm}$ contains two dark brown organic silt layers, rich in plant macrofossils. The upper organic layer contained a $6 \mathrm{~cm}$ long piece of wood, which produced two ages of $35.8 \pm 0.7 \mathrm{cal}$. ka and $35.7 \pm 0.7 \mathrm{cal}$. ka. The bottom layer was aged at $34.8 \pm 1.4 \mathrm{cal}$. ka (Marra and Thackray, 2010). The organic layers are interrupted by a $20 \mathrm{~cm}$-thick coarse sand and gravel layer. A $108 \mathrm{~cm}$-thick inorganic grey silt, containing gravels $<1 \mathrm{~cm}$ in diameter, spans $150-42 \mathrm{~cm}$. A single round cobble $(<15 \mathrm{~cm}$ in diameter) is located at the centre of the layer. There is a sharp basal contact to the overlying $5 \mathrm{~cm}$-thick dark brown organic rich silt aged $31.1 \pm 3.4$ cal. ka (Marra and Thackray, 2010). The top $37 \mathrm{~cm}$ consist of grey silt containing gravels and large cobbles ( $<15 \mathrm{~cm}$ in diameter). The top of this section appears to have slumped by ca $1 \mathrm{~m}$ and disturbance by modern tree roots has destroyed some stratigraphic detail.

\subsubsection{Section 2}

Section 2 comprises a $4.74 \mathrm{~m}$ high exposure and a short core section from underlying sediment in the main Howard River Valley. This section was described in three sub-sections (lower, middle and upper sub-section) in accord with how the terrace exposure was cleared (see Fig. 4). The complete section spans $528 \mathrm{~cm}$ in total and consists of brown, organic-rich silt between 528 and $474 \mathrm{~cm}$ interrupted by a $25 \mathrm{~cm}$-thick coarse grey sand with pebbles up to $2 \mathrm{~cm}$ in diameter. The section base is dated as $25.8 \pm 0.4 \mathrm{cal}$. ka. A grey banded silt layer, containing intermittent pebble layers, spans $474-437 \mathrm{~cm}$ and includes the top $13 \mathrm{~cm}$ of the underlying core and bottom $24 \mathrm{~cm}$ of the terrace section. Alternating brown and grey silts between 437 and $331 \mathrm{~cm}$ include a pebble layer between 391 and $383 \mathrm{~cm}$. The brown silt contains visible plant macrofossils that become noticeably less abundant up the section. At $365 \mathrm{~cm}$ a $10 \mathrm{~cm}$-thick well-sorted yellow sand, identified as Kawakawa Tephra (refer to Section 3.4) is bounded by brown organic-rich silt. The plant macrofossils lying directly beneath the tephra appear to have been flattened by the weight of the overlying deposit. This material was dated, producing two ages that have been discussed above and by Vandergoes et al. (2013). The age applied to this horizon is the modelled age $24.9 \pm 0.4 \mathrm{cal}$. ka. The alternating brown and grey silt layers continue up-section, becoming coarser with depth. The top $4 \mathrm{~cm}$ of the lower section consist of coarse unsorted pebble layer, assumed to be part of a slump.

The mid-section contains the top of the Kawakawa Tephra layer, which serves to tie stratigraphically the two sub-sections together. This mid-section is inorganic, dominated by grey silt at the base and becoming coarser upwards before grading into sand at $317 \mathrm{~cm}$. The sand layer continues to coarsen upwards and becomes unsorted coarse sand containing gravel and large cobbles. The overlying material consists of coarse sand that fines up-section. A $3 \mathrm{~cm}$-thick iron stained sandy silt marks the top of this sub-section.

The base of the upper sub-section contains the iron-stained sandy silt layer observed at the top of the middle sub-section and is overlain by a $49 \mathrm{~cm}$-thick dark brown organic-rich finely banded sandy silt with visible macrofossils. An inorganic grey silt containing 1-2 cm-thick sand bands occurs between 113 and $25 \mathrm{~cm}$. The material becomes progressively coarser up the sub-section, grading into a well sorted coarse silty sand at $93 \mathrm{~cm}$ and into poorly sorted sand, gravels and large cobbles at $49 \mathrm{~cm}$. The top $20 \mathrm{~cm}$ consists of alternating $\mathrm{mm}-\mathrm{cm}$ thick silt and sand layers containing $\mathrm{cm}$-thick brown, organic rich silt with visible plant macrofossils. The top organic layer produced an age of $22 \pm 0.4$ cal. ka. A thick fluvial cobble layer caps the top of this subsection.

\subsubsection{Section 1}

The youngest terrace section spans $280 \mathrm{~cm}$ (Fig. 4). The bottom $60 \mathrm{~cm}$ consists of yellowy brown sandy silt overlain by a $50 \mathrm{~cm}$-thick coarser grey silty sand. A $5 \mathrm{~cm}$-thick organic rich silt layer (aged $22.7 \pm 0.5 \mathrm{cal} . \mathrm{ka}$ ) lies within the bottom layer whilst another $11 \mathrm{~cm}$ thick organic unit is within the silty sand layer. Alternating sand and silt layers dominate the stratigraphy between 195 and $90 \mathrm{~cm}$ and become coarser up-section. The overlying layer consists of poorly sorted sand containing gravels and cobbles (reaching $<12 \mathrm{~cm}$ in diameter). A unit of grey silt containing $\mathrm{cm}$-thick organic-rich brown silt at the top of this section varies laterally in thickness from $80 \mathrm{~cm}$ at the sampled point to $150 \mathrm{~cm}$ and appears to fill a channel incised into the underlying material (see Fig. 5 for an example). A $10 \mathrm{~cm}$-thick organic layer forms a sharp contact with the underlying coarse layer at $80 \mathrm{~cm}$. Bulk organic material sampled by Marra and Thackray (2010) at $1 \mathrm{~cm}$ provides the age $20.9 \pm 0.5 \mathrm{cal}$. ka. The top of this section is capped by coarse fluvial material. 


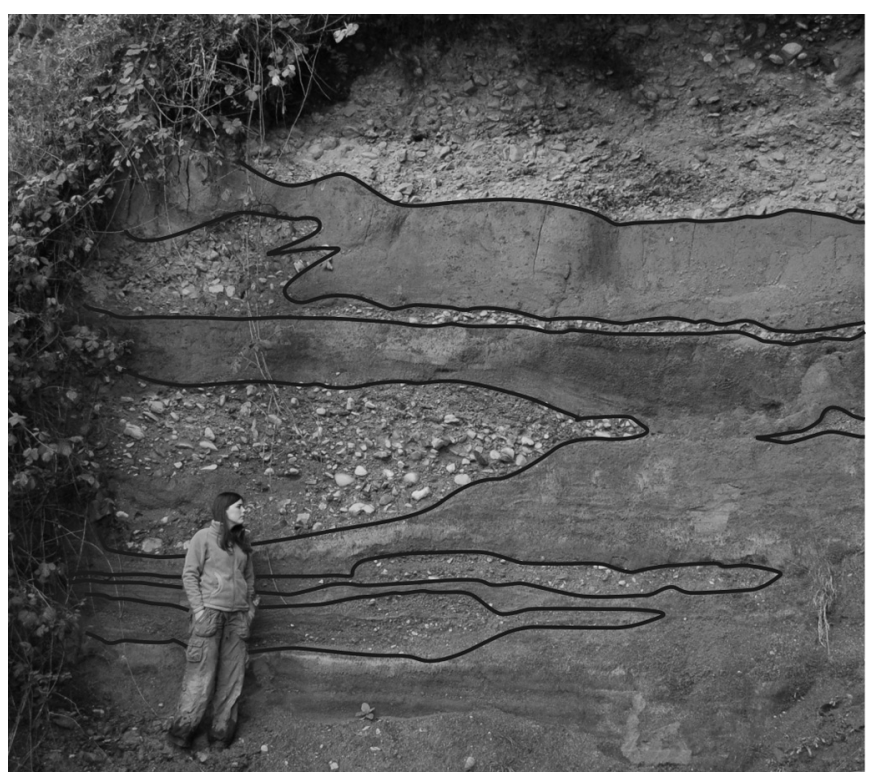

Fig. 5. An example of cut and fill in Section 1 taken upstream from the sample site with the cut and fill deposit outlined (Photo-BV Alloway)

\subsection{Palynology, phytolith and vegetation reconstruction}

A total of 45 pollen assemblages were analysed from the three sections and two cores. The pollen assemblages show there to be four well-defined vegetation changes at the site, represented as four pollen zones that were defined using chronostratigraphic constrained cluster analysis (Fig. 6; Fig. S1, Supplementary Data). In addition, three phytolith samples from Section 2 were analysed and strengthen the vegetation reconstruction for this section (Fig. 7). The ages quoted from here on are the modelled ages and the reader is referred to Table S1, Supplementary Data.

\subsubsection{Pollen zone $\mathrm{H1}: 37.7 \pm 1-37 \pm 1.1 \mathrm{cal}$. $\mathrm{ka}$}

The first zone (H1) includes pollen assemblages from the core and the lower organic units of Section 3. The top two samples from the core and bottom sample from the section overlap. Pollen zone H1 is dominated by Phyllocladus (38\%) combined with a large abundance of Poaceae and the wetland plant Cyperaceae. There are three Phyllocladus species in New Zealand, but in this context we assume the pollen represents the montane/sub-alpine shrub or small tree P. alpinus. Fuscospora and the shrubs Asteraceae and Coprosma all reach $\sim 10 \%$ abundance which, combined with $P$. alpinus, indicate woody vegetation dominated the site. N. menziesii is present in low abundances throughout this zone and reach a maximum 3\% abundance. The abundance of Cyperaceae and presence of Halocarpus suggests a large wetland component locally to the site.

The combination of Fuscospora, Poaceae and Phyllocladus alpinus implies that the site was a sub-alpine/alpine treeline environment. However, the small but significant abundance of $N$. menziesii would suggest otherwise. Moar (1970) studied the modern pollen rain at nearby Top House and St Arnaud. Although both sites were in a mixed Nothofagus forest, $N$. menziesii only represented $3 \%$ of the pollen rain, suggesting this species is underrepresented as a result of its poor pollen dispersal characteristic. The pollen assemblage at

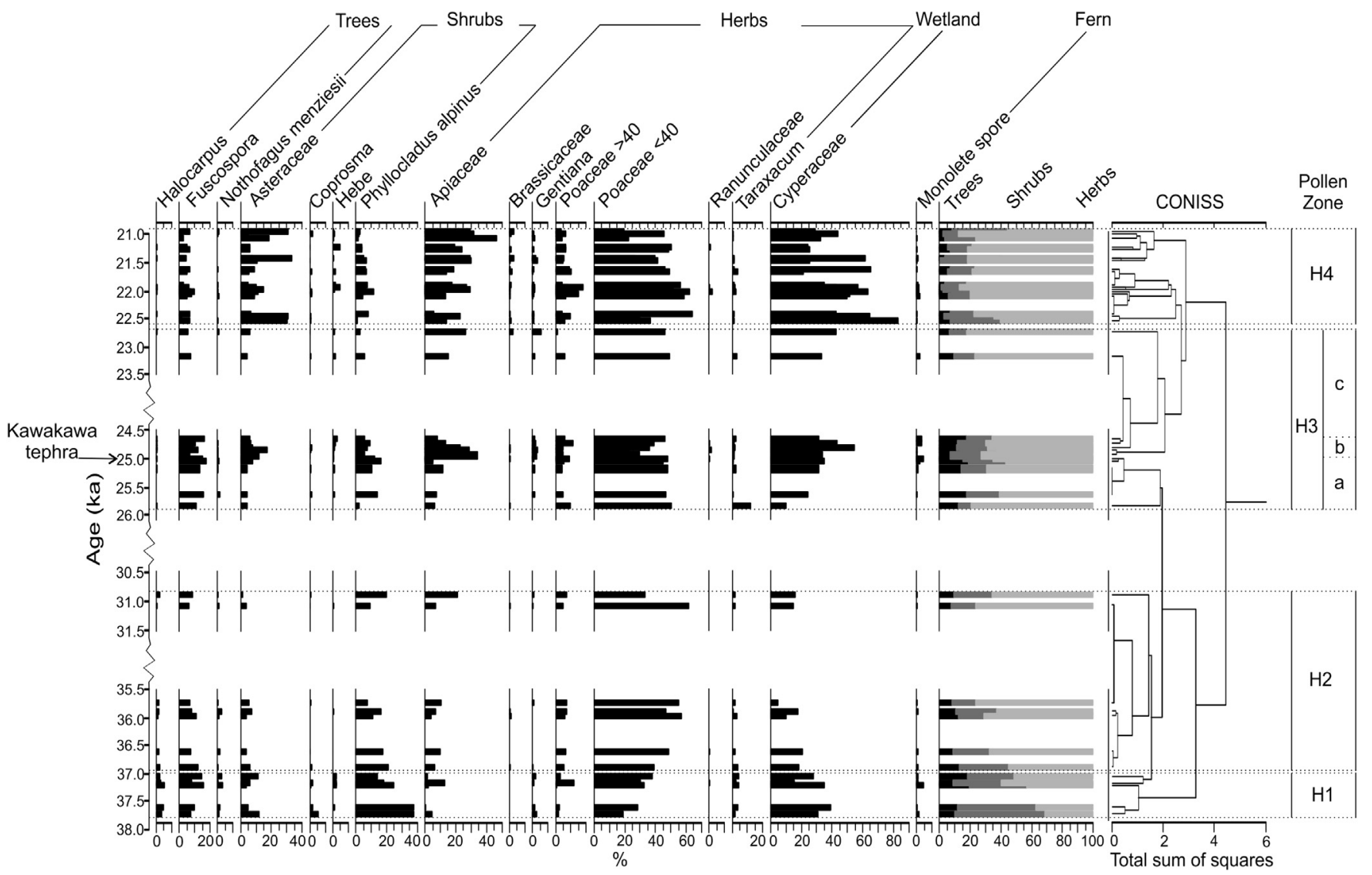

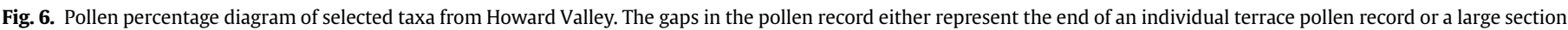
of inorganic deposit in the stratigraphy. Both of these factors produced uncertainties with the chronology and a fragmentary record. 


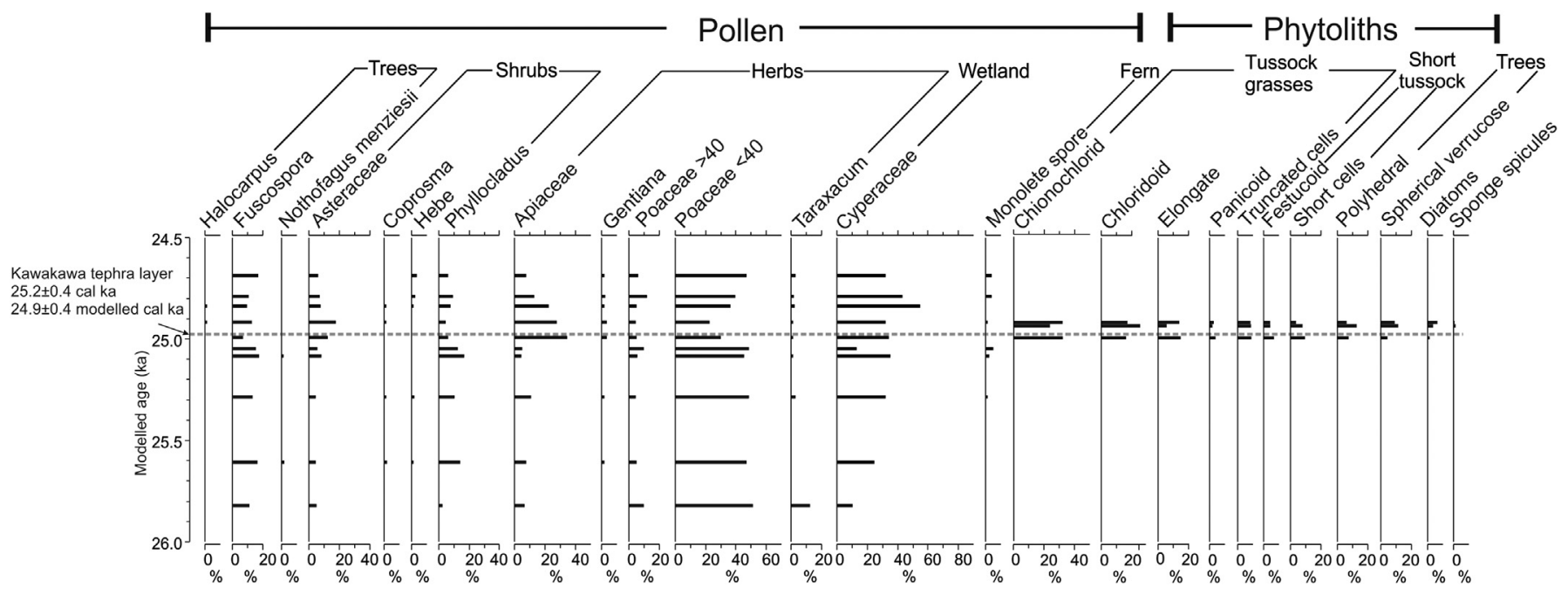

Fig. 7. Pollen and phytolith diagram of pollen zone HV3 with the location of Kawakawa Tephra marked with the dashed line.

Howard Valley is indicative of a more open environment that has a lower abundance of beech forest compared to the study by Moar (1970). Therefore, direct comparisons to the modern pollen rain studies cannot be made. However a $1-3 \%$ N. menziesii pollen, although probably representing fewer trees than in the Moar (1970) study, still indicates the tree is a significant component, thus favours the interpretation of a montane mixed beech forest rather than sub-alpine/alpine transitional vegetation for these assemblages. Thus, the assemblages overall indicate that the area was characterised by mixed montane beech forest with wetland nearby.

\subsubsection{Pollen zone H2: $36.9 \pm 1.1-30.9 \pm 3.6 \mathrm{cal}$. $\mathrm{ka}$}

The second pollen zone contains samples from the top two organic units in Section 3. The base of this zone marks a transition from a tree and shrub dominated pollen assemblage to a herb dominance that continues to increase up zone, reaching a maximum 77\%. Poaceae and Phyllocladus alpinus share an inverse relationship up the zone with Poaceae in abundance at the expense of $P$. alpinus, the latter decreasing from $21 \%$ to $9 \%$. Likewise, Fuscospora and Asteraceae abundance decrease up zone whilst Coprosma is nearly absent throughout. N. menziesii continues to be present in low abundances at the base of this zone, but decreases from $2.7 \%$ to trace values towards the top. Cyperaceae abundance also declines up zone, reducing from $18 \%$ to $4 \%$ at $35.7 \pm 0.7$ cal. ka. However, its abundance increases to $15 \%$ in the top two samples.

The continued presence of Phyllocladus alpinus, Fuscopora and $N$. menziesii at the base of this zone suggests a montane mixed beech forest component continued to be present in the region. However, at the top of this zone grass and herb taxa are dominant and only low tree abundance is recorded. This indicates a transition from a montane mixed beech forest community to a more open alpine to sub-alpine/treeline vegetation community occurred in the region during late MIS 3 . This vegetation pattern may reflect a decrease in temperature at the time causing a migration of tree taxa away from the site to lower altitudes.

$N$. menziesii retains $2.7 \%$ abundance until $35.9 \pm 0.8$ cal. ka suggesting a significant presence of this species persists in the region in the lower half of H2. Cyperaceae abundance declines between $36.9 \pm 1.1$ cal. ka and $35.9 \pm 0.8$ cal. ka, suggesting a reduction in moisture levels causing a decline in sedges and other wetland vegetation and possibly providing an increase in area suitable for grass and herb growth. The inferred changes in moisture levels are not necessarily indicative of changing climate, but could simply be a result of local changes in hydrology. However, after $35.9 \pm 0.8 \mathrm{cal}$. ka a cooling trend is evident from the decline in $N$. menziesii to trace amounts, increases in Cyperaceae and a continuing dominance of grass and herb taxa.

\subsubsection{Pollen zone H3: $25.8 \pm 0.4-22.7 \pm 0.5 \mathrm{cal}$. $\mathrm{ka}$}

Pollen zone $\mathrm{H} 3$ includes pollen samples taken from the core and lower sub-section of Section 2, including samples surrounding Kawakawa Tephra, and two samples from the base of Section 1. Assisted by cluster analysis, this zone has been split into three subzones (3a-3c). Overall, herb taxa, including Poaceae and Apiaceae, continue to dominate the pollen assemblage, however, this zone has comparably higher tree abundance than the previous zone.

\subsubsection{H3a: $25.8 \pm 0.4-25 \pm 0.4 \mathrm{cal}$. $\mathrm{ka}$}

Poaceae dominates the lower section of this zone with an abundance ranging 51-45\%. Asteraceae and Coprosma remain at similar abundance as in the previous zone. Phyllocladus alpinus initially has a low abundance of $2 \%$ at the zone base but increases to $10-18 \%$ until $25 \pm 0.4$ cal. ka. Fuscospora has a similar abundance, ranging $15-18 \%$.

\subsection{5. $\mathrm{H} 3 \mathrm{~b}: 25 \pm 0.4-24.7 \pm 0.4 \mathrm{cal} . \mathrm{ka}$}

At $\sim 25 \pm 0.4$ cal. ka, coinciding with the Kawakawa Tephra layer, a significant change in the pollen assemblages occurs. In the samples immediately above the tephra layer Fuscospora, Phyllocladus alpinus and Poaceae all show a significant decline in abundance. Conversely, Asteraceae increases and Apiaceae becomes the dominant taxon reaching 34\% abundance. Cyperaceae is present throughout the zone, ranging from 31 to 57\% with the exceptions at the zone base and at $25 \pm 0.4 \mathrm{cal}$. ka where its abundance is 10 and $13 \%$, respectively.

\subsection{6. $\mathrm{H3c:} 24.7 \pm 0.4-22.7 \pm 0.5 \mathrm{cal} . \mathrm{ka}$}

Fuscospora, Phyllocladus alpinus and Poaceae begin to steadily increase back to previous abundances at the expense of Apiaceae and Asteraceae. The pollen assemblages in subzone $\mathrm{H} 3 \mathrm{c}$ are similar to those recorded in $\mathrm{H} 3 \mathrm{a}$.

Like the previous zone, the pollen assemblage is dominated by herb taxa, but with an accompanying increase in Fuscospora and a significant abundance of Phyllocladus alpinus. Only trace amounts of $N$. menziesii was recorded and the species never exceeds $1.5 \%$ 
throughout this zone. The pollen assemblage represents an alpine to sub-alpine/treeline limit vegetation community. The greater abundance of tree pollen suggests a moderate increase of trees in the region $N$. menziesii trees could have been present at or near the site, but are unlikely to have been common. The continuous presence of Cyperaceae suggests a wetland habitat persisted throughout pollen zone $\mathrm{H} 3$.

The series of pollen assemblages above the tephra deposit shows a successional pattern of change with Asteraceae abundance increasing at the expense of Apiaceae, followed by an increase in grass, Fuscospora and Phyllocladus alpinus, all of which reach similar abundances as recorded below the tephra deposits by $\sim 24.7 \pm 0.4$ cal. ka. This vegetation succession may signify recovery following a volcanically induced vegetation change, which is discussed in Section 5.2.

In both the upper and lower units that constrain the Kawakawa Tephra, the phytolith assemblage is dominated by morphotypes most commonly isolated from Chinochloa spp., Festuca spp. and Poa spp, indicating an alpine tussock grassland with some short tussock Festuca spp. and Poa spp. In addition, morphotypes most likely to be indicative of Nothofagus spp. and broad-leaved trees (Kondo et al., 1994) are present, indicating the presence of isolated stands of trees (possibly as refugia). The caveats implicit in the use of phytoliths for interpreting likely vegetation composition are discussed further in Section 5.2.

Comparing the change in the percentage biogenic silica abundance between the lower and upper units constraining the Kawakawa Tephra, there is a slight decrease in the grass tussock species from $71 \%$ to $64 \%$ respectively. In contrast, the tree phytoliths (Nothofagus, broad-leaved species) increase from $10.2 \%$ in the lower constraining unit to $25 \%$ in the upper constraining unit. In addition, diatoms and freshwater sponge spicules present in the biogenic silica assemblage also suggest the presence of a wetland environment; percentage abundance of diatoms increases from $0.9 \%$ in the lower constraining unit to $6.5 \%$ in the upper constraining unit (Fig. 7). This agrees with the palynology of Suggate (1988) and McLea (1996) as reported in Section 2.2.

\subsubsection{Pollen zone H4: $22.5 \pm 0.7-20.9 \pm 0.5$ cal. $\mathrm{ka}$}

This fourth zone includes the top organic units of Section 2 and the majority of samples from Section 1 . The assemblages from the top organic unit in Section 2 are younger than those from the base. The samples from both sections have been placed in chronological order in Fig. 6. The zone is characterised by a dominance of Poaceae, Apiaceae and Asteraceae, which show large variability in abundance particularly towards the top of the zone. There is an overall decrease in tree and shrub abundance and a greater prevalence of alpine herb taxa including Brassicaceae and Gentiana relative to the previous three pollen zones.

Poaceae $<40 \mu \mathrm{m}$ increases in abundance ranging between 64 and $40 \%$ from $22.5 \pm 0.7 \mathrm{cal}$. ka to $21.4 \pm 0.8 \mathrm{cal}$. ka. Apiacaeae is co-dominant and increase up the zone, reaching $30-27 \%$ at $\sim 21.9$ cal. ka, and then reducing to 5-19\%. Asteraceae abundance decreases, ranging between 5 and 15\%, whilst Fuscospora, Phyllocladus alpinus and Poaceae $>40 \mu \mathrm{m}$ remain mostly between 1 and $8 \%$. From $21.4 \pm 0.8 \mathrm{cal}$. ka to the top of the zone, the pollen assemblage is characterised by increased variability in taxa abundance. Poaceae oscillates between 20 and 51\%, Apiaceae 17$47 \%$ and Asteraceae 6-33\%. A significant amount of Cyperaceae is present in the record throughout this zone, peaking at $22.5 \pm 0.7$ cal. ka with $83 \%$. However, at $22.4 \pm 0.8$ onwards its abundance becomes increasingly variable, ranging between 21 and $64 \%$, similar to the erratic pattern evident in the dryland pollen record. $N$. menziesii is present in the zone but in trace amounts, generally below $0.4 \%$.
The main vegetation type throughout pollen zone H4 is alpine herb and grassland, which occurs above the treeline in the contemporary landscape (Wardle, 1965). The presence of Asteraceae in a herb and grass dominated environment suggest the pollen from this family is more likely to represent herb rather than shrub forms. The reduced abundance of Fuscospora suggests further beech forest decline in the area. However, the low pollen abundance of the podocarps Halocarpus and Phyllocladus alpinus, and of Fuscospora along with trace amounts of $N$. menziesii indicates that these trees survived in the region. The continued presence of Cyperaceae suggests a wetland environment persisted at the site during periods of organic deposition.

\section{Discussion}

\subsection{The local depositional environment}

The stratigraphic description of the three valley fill sections indicates a dynamic depositional environment. Fluvial processes are likely to have dominated throughout but ranged from low energy phases, favouring the development of organic-rich silt formed by soil process in suitable locations on the valley floor, to high-energy phases that resulted in transport and deposition of coarser sediment. The erosional contacts, evident in the stratigraphy, indicate periods of hiatus and thus a discontinuous record. The organic sediments analysed for pollen are likely to result from localised temporary back ponding and soil development providing intermittent 'windows' into the nature of both valley floor and valley side environments as well as glimpses of the changing regional vegetation cover. These windows are a serendipitous result of processes of aggradation and incision in the valley driven by base level changes that were likely caused by bedrock constriction and episodic damming in either the Buller River Valley, Howard River Valley, or a combination of the two. The serendipitous nature of these windows, the discontinuous record they reveal, and the variable local depositional environment need to be borne in mind when interpreting the pollen assemblages, especially in terms of climate change.

The valley fill ages confirm the complex depositional and erosional environment of the site. As mentioned earlier, the terraces are not topographically paired and, apart from a few exceptions, units cannot be stratigraphically traced from one section to another. However, the sections can be chronologically related to produce a site record, albeit fragmentary, spanning $37.7 \pm 1-$ $20.9 \pm 0.5$ cal. ka. The oldest organic rich layer in Section 3 has a modelled age of $37.7 \pm 1 \mathrm{cal}$. ka which is $15.3 \mathrm{ka}$ older than the base of Section 1, but lies at a similar elevation. Both of these sections are adjacent to a small but active stream. It is therefore likely that Section 1 fills a stream channel cut into the valley fill of Section 3. Challis et al. (1994) photographed the section containing Kawakawa Tephra that clearly shows the tephra and enveloping strata occupying a channel cut into an older sequence of organic-rich fluviatile deposits. This process of channelling and infilling provides a likely explanation for the large age differences between the three sections.

\subsection{The use of phytolith assemblages for interpreting vegetation change}

While the phytolith assemblage offers another record for reconstructing past vegetation, there are certain caveats in their interpretation. It is not possible to unequivocally attribute individual species to particular phytolith morphotypes, but it is possible to indicate genera. For example, similar morphotypes (chinochloid, chloridoid, panicoid, festucoid, short cells, elongate cells) are all found in Chinochloa spp. and Festuca spp.; while Poa 
spp. also contributes festucoid morphotypes (Kondo et al., 1994; Marx et al., 2004). However, Hughes (2008) proposed that the most likely species could be tentatively inferred, based on the presence of modern species within the geographical area of study. Edgar and Connor (2010) indicate that present day sub-alpine to alpine tussock grasslands for the northern part of the South Island include Chinochloa (C. australis, C. conspicua, C. rubra, C. pallens), Rytidosperma ( $R$. viride, $R$. australe), Festuca (F. matthewsii, F. novae-zealandae) Poa ( $P$. Novae-zealandae, $P$. dipsacea, $P$. hesperia, $P$. pratensis, $P$. tonsa). We thus infer that Chinochloa spp., Festuca spp., Rytidosperma spp. and Poa spp. are most likely to be the dominant grass tussock genera represented by the phytolith morphotypes present in the units studied.

For tree and woody species phytoliths, similar caution in interpretation of morphotypes must be applied. While Underwood (2006) in his study of soil phytoliths under a treeline ecotone in the South Island, New Zealand, demonstrated that spherical verrucose morphotypes do occur under $N$. menziesii. Other research (Shulmeister et al., 1999; Carter, 2000, 2002; Carter and Lian, 2000) attributed spherical verrucose morphotypes to "undifferentiated trees and shrubs". In addition, spherical verrucose morphotypes may have originated from species more representative of an ecotone changing from forest to open grassland - such as Dracophyllum longifolium, Leptospermum spp. and Phyllocladus alpinus. Moreover, Kondo et al. (1994) states that spherical verrucose morphotypes can also be attributed to the Fuscospora group of Nothofagus. It is also important to consider that phytolith production from plants such as gymnosperms (Podocarpaceae) is rare or absent (Kondo et al., 1994), leading to possible under representation in the phytolith record, compared to the pollen record.

\subsection{Environmental reconstruction}

\subsubsection{Late MIS 3}

Howard Valley provides a rare terrestrial record extending back into MIS 3 in a region that experienced prominent glaciation. The vegetation inferred from pollen zone $\mathrm{H} 1$, dated to $37.7 \pm 1-$ $37 \pm 1.1 \mathrm{cal}$. ka, is a mixed beech forest containing Phyllocladus alpinus and Cyperaceae-dominated wetland areas. The presence of this community continued into zone $\mathrm{H} 2$ with local presence of $N$. menziesii likely to have persisted until $35.9 \pm 0.7 \mathrm{cal}$. ka. In the same sample horizons, Marra and Thackray (2010) reported abundant $N$. menziesii leaves and beetles associated with forest and forest litter habitats, consistent with the pollen-based vegetation reconstruction. Nevertheless, the leaf and beetle evidence confirms the under representation of $N$. menziesii in the pollen record and highlights the importance of identifying this taxon in pollen-based palaeovegetation, even when at low abundances.

$N$. menziesii forest in the region today is limited to 9001100 m.a.s.l so the Howard Valley evidence suggests that this species was 400-600 $\mathrm{m}$ lower during MIS 3 than its current altitudinal limit assuming the site was close to the upper limit of $N$. menziesii zone. At an ELR of $0.5{ }^{\circ} \mathrm{C} / 100 \mathrm{~m}$, this represents an MIS 3 temperature depression of $2-3{ }^{\circ} \mathrm{C}$. Such an interpretation is consistent with evidence from the North Island that also suggests MIS 3 was $\sim 3{ }^{\circ} \mathrm{C}$ cooler than current conditions (McGlone and Topping, 1983; Marra et al., 2009).

\subsubsection{Late MIS 3 cooling trend}

The top of pollen zone $\mathrm{H} 2(35.7 \pm 0.7 \mathrm{cal}$. ka) marks a vegetation change from montane/sub-alpine mixed beech forest to a grass and herb dominated sub-alpine/treeline community. $N$. menziesii pollen is present only sporadically and at trace values, suggesting this tree was absent or rare in the local environment. The pollen assemblage of Fuscospora, Phyllocladus alpinus and the large abundance of grasses, including an increase in alpine tussocks, is characteristic of the sub-alpine/treeline vegetation zone in the contemporary environment. Like the pollen evidence, the beetle and plant macrofossil record from the same horizons indicates a decrease in forest taxa at the site and grass material dominates the plant macrofossil record (Marra and Thackray, 2010). The vegetation change demonstrates cooling in the region had already commenced by $35.7 \pm 0.7$ cal. ka and climate was significantly colder by $31.1 \pm 3.5 \mathrm{cal}$. ka. The onset of this cooling phase cannot be clearly determined because of a hiatus in the pollen record, marked by the deposition of the $\sim 1 \mathrm{~m}$ thick, inorganic, grey silt and gravels that separate the two organic layers in $\mathrm{H} 2$.

Globally, ice sheet growth began sometime between $\sim 33$ and 26.5 cal. ka, marking the start of the global Last Glacial maximum (Clark et al., 2009). In New Zealand, a range of proxy evidence has been interpreted as indicating onset of the LGCP between 29 and 27 cal. ka (Newnham et al., 2007a; Alloway et al., 2007). The Howard Valley record provides an incomplete reconstruction, lacking data between $35.7 \pm 0.7$ and $31.1 \pm 3.5$ cal. ka. Over this period vegetation changed from mixed montane beech forest to alpine grassland/sub-alpine treeline vegetation suggesting climatic deterioration began prior to $35.7 \pm 0.7 \mathrm{cal}$. ka and provides a minimum constraint on the onset of the local LCGP. Other evidence from New Zealand also implies an earlier glacial advance and cooling. A pollen record from Okarito Pahiki, to the southwest of Howard Valley, also supports a cooler than present MIS 3 and contains evidence of progressive cooling represented by a number of grass peaks throughout MIS 3 (Newnham et al., 2007a). The Okarito Pahiki pollen record indicates the start of a significant increase in herb abundance that culminates at the onset of the LCGP, began $\sim 35$ cal. ka (Vandergoes et al., 2005) and suggest initiation of significantly cooling began at this time. Alloway et al. (1992) and Nelson et al. (1993) recorded a peak in aerosol quartz accumulations, which may be associated with increased glacial activity, occurring 34.4 cal. ka. Likewise moraine evidence from the South Island also suggests earlier ice advance during late MIS 3 (Almond et al., 2001; Suggate and Almond, 2005; Sutherland et al., 2007). Elsewhere in the Southern Hemisphere, moraine exposure ages provide evidence of glacial advance in Chile between 35 and 32 cal. ka (Denton et al., 1999) and at $\sim 31$ cal. ka in Tasmania (Fink et al., 2000). In Antarctica, a temperature reconstruction from the Vostock Ice Core record indicates a cooling inflection in temperature gradient starting $\sim 35$ cal. ka (Petit et al., 1999). The global sea level curve records a rapid decrease in sea level between $\sim 33$ and 32 cal. ka (Lambeck and Chappell, 2001; Lambeck et al., 2002). An earlier onset of the LGCP at Howard Valley is therefore consistent with a wide range of evidence in the region and at comparable southern hemisphere locations and even on a global scale.

\subsubsection{Vegetation change during the LGCP}

Throughout the LGCP, all three proxies indicate that the site is dominated by alpine herb and grass taxa, although tree and woody shrubs persist. In the pollen record, however, a notable increase in tree and shrub pollen occurs during the mid-LGCP with Fuscospora pollen abundance ranging $18-15 \%$ between $25.8 \pm 0.4$ cal. ka to $25 \pm 0.4$ cal. ka (assemblages below the Kawakawa Tephra) and $24.7 \pm 0.4 \mathrm{cal}$. ka (38 cm above the tephra). Evidence from the plant macrofossil and beetle analysis by Marra and Thackray (2010) concluded that at the same sediment horizons the site was a mixed podocarp beech forest. However, the plant macrofossils are mainly grass remains and include tussock material. Plant macrofossils found in the organic horizon directly below the Kawakawa Tephra layer contained two N. menziesii leaves and a Podocarpus leaf assumed to be Podocarpus hallii, the present distribution of which spans from the lowland to the sub-alpine zone (Poole and Adam, 
1964). Marra and Thackray (2010) suggest the mixed forest community is of a similar composition to sub-alpine scrub located at the altitudinal tree limit in the modern environment (Wardle, 1980). We concur with this conclusion. The combination of herb pollen dominance with moderate levels of Fuscospora and Phyllocladus alpinus pollen is consistent with a situation close to the contemporary sub-alpine/alpine transition (Wardle, 1980). However, classifying a sub-alpine scrub community, indicative of the treeline, as forest, as concluded by Marra and Thackray (2010), may be misleading and imply a discrepancy between the pollen and beetle records that does not exist. McGlone et al. (2010) have also argued that the different vocabulary used for beetle and pollen vegetation reconstructions, in this instance the term "woody", has caused an implied discrepancy between records. The term 'Forest', like woody, is generic and open to interpretation. Forest can be used to describe a broad range of vegetation communities spanning from lowland forest to sub-alpine forest. The use of this term in palaeovegetation and palaeoclimate research is therefore not useful and does not clearly describe the vegetation community represented in the proxy record. Using a standardised vocabulary that provides explicit vegetation classifications would help reconcile disparities between some records and, conversely, highlight the differences as well.

The pollen assemblage directly underlying the Kawakawa Tephra layer and the subsequent assemblages above indicate a disruption to the vegetation, presumably associated with this event (Fig. 7). This is characterised by an initial decrease in Fuscospora, Phyllocladus alpinus and Poaceae and an increase in Apiaceae, followed by a successional pattern with the pollen assemblage returning to a similar composition as that prior to the disruption. Three phytolith samples were taken from the site at Section 2, one taken below the Kawakawa Tephra and two above (Figs. 2 and 8). Considering the caveats discussed above and the limited number of samples, the phytolith record supports the vegetation changes (at the time of the Kawakawa deposition event) interpreted from the

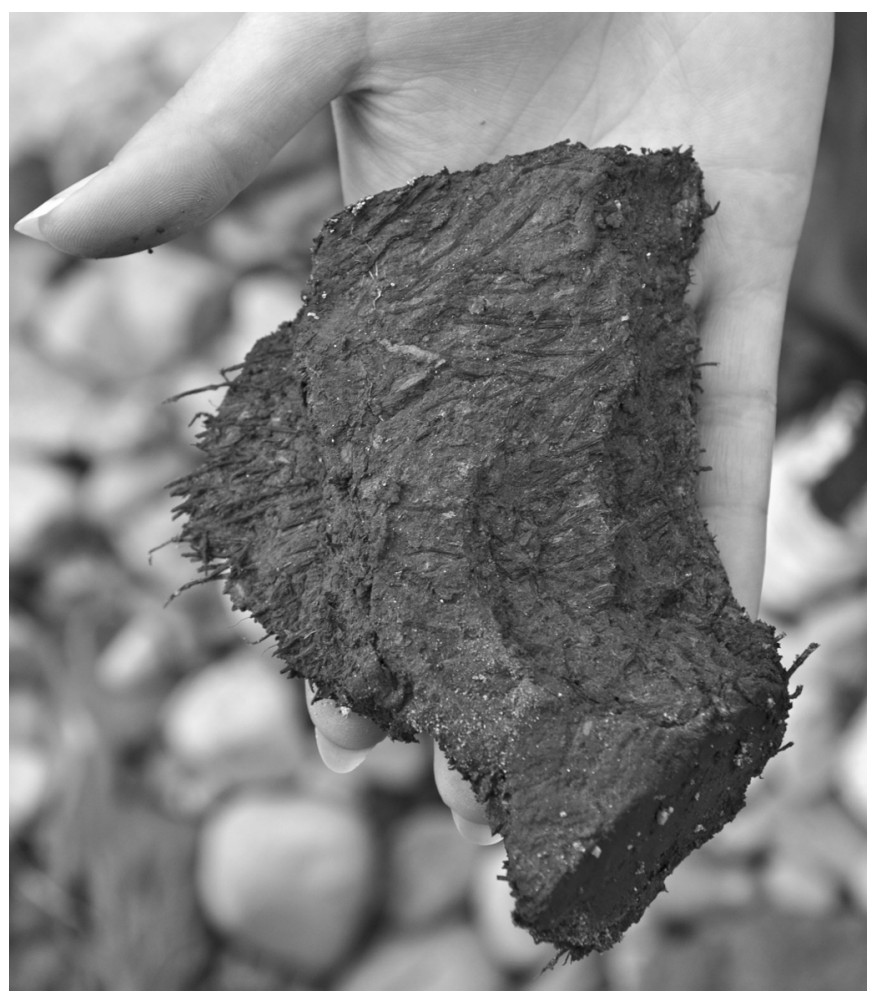

Fig. 8. Remains of plant material in the organic rich silts that were flattened by the weight of the overlying Kawakawa Tephra. pollen record. In addition, changes in the phytolith assemblage indicate a vegetation disruption coinciding with the tephra deposition. At the time of the Kawakawa Tephra deposition event, the phytoliths indicate a sub-alpine environment dominated by tall tussock grasses (Chinochloa spp.) with some short grasses (Poa and Festuca), along with isolated stands of Nothofagus. Immediately after the Kawakawa Tephra deposition event, Chinochloa spp remain unchanged, but there is a decline in short grass phytoliths, which is also shown in the pollen record. However, the abundance of phytolith morphotypes associated with Nothofagus spp. (spherical verrucose) slightly increases whilst the pollen record shows a decline. Nevertheless, there is a continuous presence of Fuscospora pollen (which also contributes to spherical verrucose morphotypes), indicating isolated beech trees were present in the landscape after the tephra deposit that would still contribute to the presence of phytoliths in the soils.

There could be a number of causes for this change in vegetation described above, but one possibility is a volcanic induced vegetation response. The horizon directly underlying the tephra contains a layer of plant macrofossils squashed horizontally by the overlying $10 \mathrm{~cm}$-thick tephra deposit (Fig. 8). Even a $10 \mathrm{~cm}$ thick tephra fall is enough to destroy crops, strip leaves from trees and break branches (Blong, 1984; Houghton et al., 1988). It is likely that the tephra has compacted as a result of burial, and that the original depositional thickness was greater than $10 \mathrm{~cm}$, suggesting syn-depositional damage to vegetation regionally may have been severe. At Howard Valley it is likely that local grasses and sedges were buried and the few tree species present in the area were damaged significantly enough to cause a decline in the pollen abundance of these taxa.

Newnham et al. (2007b) identified a vegetation disturbance attributed to Kawakawa Tephra in Kohoura pollen record, which contains a $2 \mathrm{~cm}$ thick layer. The pattern of vegetation change has a similar signal as a brief period of climatic deterioration during a period of relatively milder conditions. This signal is marked by an expansion of grass in the area and suggests widespread landscape disturbance that briefly affected upon the vegetation. Whether the vegetation change was influenced by volcanic cooling or volcanic disturbance could not be resolved (Newnham et al., 2007b). To some extent the pattern of vegetation change at Howard Valley also shares a similar signal as a climate cooling with the tree abundance declining. However, grass abundance also declines and, combined with a $10 \mathrm{~cm}$ thick tephra deposit, it is likely the vegetation disruption evident in the pollen record is a primary response to burial and damage caused by ash ladening.

Between $22.5 \pm 0.7$ and $20.9 \pm 0.5$ cal. ka alpine grass and herb taxa continued to dominate the pollen record whilst Fuscospora and shrub abundance declined further. The beetle and plant macrofossil record follows a similar pattern with grass material dominating the record and evidence of forest and shrub material becoming scarce or absent (Marra and Thackray, 2010). This suggests a further migration of trees away from the site, indicating further cooling at this time. This late LGCP vegetation community is consistent with pollen records in the region (refer to Section 2.2) and elsewhere in the South Island (McGlone et al., 2010; Newnham et al., 2013), suggesting that extensive forest stands could not grow at the site during the coldest conditions. Nevertheless, at Howard Valley, the continued presence of Fuscospora and trace abundance of $N$. menziesii pollen suggest the presence of these trees within refugia occupying sheltered areas in the region even during the coldest periods.

\subsubsection{Pattern of climate change during the LGCP}

The Howard Valley palaeovegetation evidence clearly identifies a two phase cooling during the LGCP, although it must be 
emphasised that the fragmentary nature of the record means that this time interval is incompletely represented. In the first phase, between $31.1 \pm 3.5$ and $35.7 \pm 0.7 \mathrm{cal}$. ka, a Nothofagus sub-alpine treeline community is indicated. In the modern environment, $N$. solandri var. cliffortiodes grows between 1100 and $1400 \mathrm{~m}$ a.s.l. For the upper limit of this species to reduce in elevation to the site at $500 \mathrm{~m}$ a.s.l a minimum temperature depression of $3-4.5{ }^{\circ} \mathrm{C}$ is necessary. In the second phase the continued decline in tree abundance and dominance of sub-alpine/alpine taxa suggest colder conditions were experienced at the site. To lower the sub-alpine zone by more than $700 \mathrm{~m}$ in altitude would require a MAT depression of $\geq 4.5^{\circ} \mathrm{C}$. The pollen assemblages suggest the period $31.1 \pm 3.5-35.7 \pm 0.7 \mathrm{cal}$. ka, although colder than the previous pollen zone, was milder than the coldest period spanning $22.5 \pm 0.7-20.9 \pm 0.5$ cal. ka.

It is inferred from the pollen and beetle evidence that the LGCP was a period of variable climate in the Howard Valley region showing three distinct climate phases. This includes the initial cold phase at the onset of the LGCP ( $\sim 31$ cal. ka), a milder, but still cold, phase during the mid-LGCP $(\sim 25.8-24.7$ cal. ka), and a very cold period late LGCP ( $\sim 22.5$ cal. ka), although the discontinuous nature of the Howard Valley record prevents the timing and nature of these transitions to be defined precisely. This pattern of LGCP climate has been identified in other, more continuous records, from across New Zealand (see Table 3) indicating that this is not only a regional signal but New Zealand wide. Using the Kawakawa Tephra layer as an independent, widespread chronostratigraphic marker, it is clear that a period of milder climate began before and persisted after this tephra was deposited (Newnham et al., 2007a, 2007b). In south Westland the Kawakawa Tephra layer is found within buried soil horizons that are sandwiched between loess deposits and tills related to two glacial advances (Suggate and Almond, 2005). Periods of rapid loess accumulation are associated with cold periods where there is a large sediment supply. Reduced loess accumulation allowing for soil development in south Westland is assumed to be caused by glacial recession and linking the deposition of the Kawakawa Tephra to a period of climatic amelioration (Suggate and Almond, 2005). The precise timing of this milder interval cannot be constrained at Howard Valley and the different ages used for the Kawakawa Tephra layer hinders a definitive age for this event. However palaeoenvironmental records from the sites mentioned above indicate a period of significant climate variation occurred synchronously across New Zealand.

The pollen and beetle assemblages in zone H4, $22.5 \pm 0.7-$ $20.9 \pm 0.5$ cal. ka, suggests this period was the coldest reconstructed in the Howard Valley record and corresponds with the timing of greatest ice advance in the region, when glaciers extended to $650 \mathrm{~m}$ a.s.l at Lake Rotoiti and $450 \mathrm{~m}$ a.s.l at Lake Rotoroa

\section{Table 3}

A table illustrating the three climate phases during the LGM from different records New Zealand. Due to the different ages used for the Kawakawa Tephra there is a difference in the timing of these events however the milder interval represents material that envelopes Kawakawa Tephra and therefore the sites can be stratigraphically constrained.

\begin{tabular}{lllc}
\hline Site & $\begin{array}{l}\text { LGCP onset } \\
\text { (cold) }\end{array}$ & $\begin{array}{l}\text { Mid-LGCP milder } \\
\text { interval }\end{array}$ & Late-LGCP (cold) \\
\hline Howard Valley & $\sim 31.1$ cal. ka & $25.8-22.7$ cal. ka & $\sim 22.5-20.9$ cal. ka \\
Okarito $^{\text {a }}$ & $29-28$ cal. ka & $27-21$ cal. ka & $21-18$ cal. ka \\
Auckland $^{\text {bu }}$ & $28-21$ cal. ka & $27-21$ cal. ka & $21-18$ cal. ka \\
$\begin{array}{c}\text { New Zealand climate } \\
\text { event stratigraphy }\end{array}$ & $28 \mathrm{ka}$ & $27-21 \mathrm{cal} . \mathrm{ka}$ & $21-18 \mathrm{cal} . \mathrm{ka}$ \\
\hline
\end{tabular}

\footnotetext{
a Newnham et al. (2007a).

b Newnham et al. (2007b).

c Alloway et al. (2007).
}

(Fig. 1). In the New Zealand INTIMATE event stratigraphy the period spanning $21 \mathrm{cal}$. ka to $18 \mathrm{cal}$. ka is a cold climate period at the end of the LGCP (Alloway et al., 2007). This event broadly corresponds with pollen zone $\mathrm{H} 4$, with the upper age boundary within the limits of error, suggesting a New Zealand wide cold event occurred at this time. The estimated minimum MAT depression at Howard Valley during the late LGCP of $\geq 4.5^{\circ} \mathrm{C}$ is consistent with a range of New Zealand palaeoenvironmental records from terrestrial sites (e.g. Porter, 1975; Soons, 1979; McGlone and Topping, 1983; Newnham et al., 2013), marine records (e.g. Pelejero et al., 2006; Barrows et al., 2007), and climate models (Drost et al., 2007).

\section{Summary and conclusions}

The pollen record presented here extends upon the findings of previous work at this site to provide a multi-proxy reconstruction of vegetation and inferred climate. The pollen record indicates a mixed montane beech forest persisted in southeast Nelson during the cooler MIS 3, but likely disappeared from the region during the subsequent colder LGCP. Climate cooling began in the region as early as $35.7 \pm 0.7 \mathrm{cal}$. ka and had become significantly colder by $31 \mathrm{cal}$. ka, suggesting the onset of the LGCP began prior to this and earlier than defined in the NZ-INTIMATE climate event stratigraphy. This broadly corresponds with evidence of cooling and increased glacial activity elsewhere in New Zealand (e.g. Almond et al., 2001; Vandergoes et al., 2005), glacial advance in Chile (Denton et al., 1999), cooling in Antarctica (Petit et al., 1999) and global ice sheet growth (Clark et al., 2009) and supports an onset of cooling beginning in the latter part MIS 3. The record suggests a three phase climatic pattern during the LGCP. At the onset of the LGCP, the Howard Valley region supported a grassland dominated subalpine/treeline limit vegetation community with a significant shrub and woody vegetation cover. This cold phase was interrupted by a milder interval with greater tree abundance from 25.8 to 24.7 cal. ka, occurring before and continuing after the deposition of Kawakawa Tephra. A minor vegetation disruption during this period is attributed to burial and damage caused by the tephra fall. The coldest phase of the LGCP was dominated by a mixed grass and herb alpine/sub-alpine vegetation community and began $\sim 22.5$ cal. ka. This pattern of climate change during the LGCP is similar in timing and structure to the New Zealand INTIMATE event stratigraphy (Alloway et al., 2007). Although both the pollen and beetle evidence suggest Howard Valley did not support forest during this coldest phase of the LGCP, they nevertheless point to isolated tree refugia in sheltered areas. Burge and Shulmeister (2007) concluded that climates during the latter part of the LGCP could not be as harsh as postulated by the pollen records due to the presence of woody vegetation at that time. However, the Howard Valley record indicates that tree and shrub taxa could persist in isolated stands despite the cold and harsh climate conditions and supports a $4-5{ }^{\circ} \mathrm{C}$ cooling in MAT as concluded from other proxy and simulated climate reconstructions for New Zealand (e.g. McGlone and Topping, 1983; Pelejero et al., 2006; Drost et al., 2007). The radiocarbon chronology developed here for the site supports a younger age for the Kawakawa Tephra proposed by Vandergoes et al. (2013).

\section{Acknowledgements}

We thank Maureen Marra who showed us the site and provided important sampling advice. We are grateful to Christopher Bronk Ramsey for his advice with the radiocarbon calibration and outlier models, Aidan Allan for microprobing the Kawakawa Tephra and Sam Kelly and Matt Ryan for their help with sample collection. We also like to thank Peter Almond and an anonymous reviewer for 
useful comments and improvements to the manuscript. This work was completed under a Victoria University of Wellington PhD scholarship to Callard.

\section{Appendix A. Supplementary data}

Supplementary data related to this article can be found at http:// dx.doi.org/10.1016/j.quascirev.2012.12.007.

\section{References}

Allan, A.S.R., Baker, J.A., Carter, L., Wysoczanksi, R.J., 2008. Reconstructing the Quaternary evolution of the world's most active silica volcanic system: insights from an $\sim 1.65$ Ma deep ocean tephra record sourced from Taupo Volcanic Zone, New Zealand. Quaternary Science Reviews 27, 2341-2360.

Alloway, B.V., Stewart, R.B., Neall, V.E., Vucetich, C.G., 1992. Climate of the last glaciations in New Zealand, based on aerosolic quartz influx in an andesitic terrain. Quaternary Research 38, 170-179.

Alloway, B.V., Lowe, D.J., Barrel, D.J.A., Newnham, R.M., Almond, P.C., Augustinus, P.C., Bertler, N.A.N., Carter, L., Litchfield, N.J., McGlone, M.S. Shulmeister, J., Vandergoes, M.J., Williams, P.W., 2007. Towards a climate even stratigraphy for New Zealand over the past 30000 years (NZ-INTIMATE project). Journal of Quaternary Science 22, 9-36.

Almond, P.C., Moar, N.T., Lian, O.B., 2001. Reinterpretation of the Glacial chronology of South Westland, New Zealand. New Zealand Journal of Geology and Geophysics $44,1-15$.

Barrows, T.T., Lehman, S.J., Fifield, L.K., De Deckker, P., 2007. Absence of cooling in New Zealand and the adjacent ocean during the younger dryas chronozone. Science 318, 86-88.

Blong, R.J., 1984. Volcanic Hazards. Academic Press, Sydney, pp. 424.

Burge, P.I., Shulmeister, J., 2007. Re-envisioning the structure of Last Glacial vegetation in New Zealand using beetle fossils. Quaternary Research 68, 121-132.

Brown, T.A., Nelson, D.E., Mathewes, R.W., Vogel, J.S., Southron, J.R., 1989. Radiocarbon dating of pollen by accelerator mass spectrometry. Quaternary Research $32,205-212$.

Campbell, I.B., 1986. New occurrences and distribution of Kawakawa Tephra in South Island, New Zealand. New Zealand Journal of Geology and Geophysics 29 $425-435$.

Carter, J., 2000. Phytoliths from loess in Southland, New Zealand. New Zealand Journal of Botany 38, 325-332.

Carter, J., 2002. Phytolith analysis and paleoenvironmental reconstruction from lake Poukawa core, Hawkes Bay, New Zealand. Global and Planetary Change 33, 257-267.

Carter, J.A., Lian, O.B., 2000. Paleoenvironmental reconstruction from the Last Interglacial using phytolith analysis, southeastern North Island, New Zealand. Journal of Quaternary Science 15, 733-743.

Clark, P.U., Dyke, A.S., Shakun, J.D., Carlson, A.E., Clark, J., Wohlfarth, B. Mitrovica, J.X., Hostetler, S.W., McCabe, A.M., 2009. Science 325, 710-714.

Challis, G.A., Johnston, M.R., Lauder, W.R., Suggate, R.P., 1994. Geology of the Lake Rotoroa Area. In: Geologic Map, vol. 8. Institute of Geological and Nuclear Science, Lower Hutt, New Zealand.

Denton, G.H., Heusser, C.J., Schüchter, C., Marchant, D.R., 1999. Interhemispheric linkage of palaeoclimate during the last glaciations. Geografiska Annaler 88, 107-153.

Drost, F., Renwick, J., Bhaskaran, B., Oliver, H., McGregor, J., 2007. A simulation of New Zealand's climate during the Last Glacial Maximum. Quaternary Science Reviews 26, 2505-2525.

Edgar, E., Connor, H.E., 2010. Flora of New Zealand. In: Grasses, vol. V. Manaaki Whenua Press.

Fink, D., McKelvey, B., Hannan, D., Newsome, D., 2000. Cold rocks, hot sands: in-situ cosmogenic applications in Australia at ANTARES. Nuclear Instruments and Methods in Physics Research 172, 838-846.

Houghton, B.F., Latter, J.H., Froggatt, P.C., 1988. Volcanic hazards in New Zealand. Geological Society of New Zealand Miscellaneous Publication. 41d, 1-54.

Hughes, M.W., 2008. Late Quaternary Landscape Evolution and Environmental Change in Charwell Basin, South Island, New Zealand. Unpublished PhD thesis, Lincoln University, New Zealand.

Kelly, A., Charman, D., Newnham, R.M., 2010. A Last Glacial Maximum pollen record from Bodmin Moor showing a possible cryptic northern refugium in southwest England. Journal of Quaternary Science 25, 296-308.

Kondo, R., Childs, C., Atkinson, I., 1994. Opal Phytoliths of New Zealand.

Lambeck, K., Chappell, J., 2001. Sea level change through the Last Glacial cycle. Science 292, 679-686.

Lambeck, K., Yokoyama, Y., Purcell, T., 2002. Into and out if the Last Glacial Maximum: sea-level change during Oxygen Isotope Stages 3 and 2. Quaternary Science Reviews 21, 343-360.

Large, M.F., Braggins, J.E., 1991. Spore Atlas of New Zealand Ferns and Fern Allies. SIR Publishings, Wellington, pp. 168.

Lowe, D.J., Shane, P.A.R., Alloway, B.V., Newnham, R.M., 2008. Fingerprints and age models for widespread New Zealand tephra marker beds erupted since 30,000 years ago: a framework for NZ-INTIMATE. Quaternary Science Reviews 27, 95-126.

Lu, H., Wu, N., Yang, X., Jiang, H., Liu, K., Liu, T., 2006. Phytoliths as quantitative indicators for the reconstruction of past environmental conditions in China I: phytolith-based transfer functions. Quaternary Science Reviews 25, 945-959.

Mabin, M.C.G. 1983. Late Otiran sedimentation and Glacial chronology of Warwick Valley, south east Nelson. New Zealand Journal of Geology and Geophysics 26, 186-195.

Madella, M., Alexandre, A., Ball, T., 2005. International Code for Phytolith Nomenclature 1.0.

Marx, R., Lee, D.E., Lloyd, K.M., Lee, W.G., 2004. Phytolith morphology and biogenic silica concentrations and abundance in leaves of Chinochloa (Dantoniae) and Festuca (Poeae) in New Zealand. New Zealand Journal of Botany 42, 677-691.

Marra, M.J., Leschen, R., 2004. Late Quaternary paleoecology from forest beetle communities in the Awatere Valley, South Island, New Zealand. Journal of Biogeography 31, 571-586.

Marra, M.J., Crozier, M., Goff, J., 2009. Palaeoenvironment and biogeography of a late MIS 3 fossil beetle fauna from South Taranaki, New Zealand. Journal of Quaternary Science 24, 97-107.

Marra, M.J., Thackray, G.D., 2010. Glacial forest refugium in Howard Valley, South Island, New Zealand. Journal of Quaternary Science 25, 309-319.

McCaplin, J.P., 1992a. Glacial and postglacial geology near Lake Tennyson, Clarence River. New Zealand Journal of Geology and Geophysics 35, 201-210.

McCaplin, J.P., 1992b. Glacial geology of the upper Wairau Valley, Marlborough, New Zealand. New Zealand Journal of Geology and Geophysics 35, 211-222.

McGlone, M.S., 1985. Plant biogeography and the late Cenozoic history of New Zealand. New Zealand Journal of Botany 23, 723-749.

McGlone, M.S., Topping, W.W., 1983. Late Quaternary vegetation, Tongariro region, central North Island, New Zealand. New Zealand Journal of Botany 21, 53-76.

McGlone, M.S., Moar, N.T. 1998. Dryland Holocene vegetation history, central Otago and the Mackenzie Basin, South Island, New Zealand. New Zealand Journal of Botany 36, 91-111.

McGlone, M.S., Newnham, R.M., Moar, N.T., 2010. The vegetation cover of New Zealand during the Last Glacial Maximum: do pollen records under-represent woody vegetation? Terra Australis 32, 49-68.

McLea, W.L., 1996. The late-Quaternary pollen record of south-east Nelson, South Island, New Zealand. New Zealand Journal of Botany 34, 523-538.

Meyer, H.W., 1992. Lapse rates and other variables applied to estimating paleoaltitudes from fossil floras. Palaeogeography, Palaeoclimatology, Palaeoecology 99, 71-99.

Moar, N.T., 1970. Recent pollen spectra from three localities in the South Island, New Zealand. New Zealand Journal of Botany 8, 210-221.

Moar, N.T., 1971. Contributions to the Quaternary history of the New Zealand flora 6. Aranuian pollen diagrams from Canterbury, Nelson, and north Westland, South Island. New Zealand Journal of Botany 9, 80-145.

Moar, N.T., 1980. Late Otiran and early Aranuian grassland in central South Island. New Zealand Journal of Ecology 3, 4-12.

Moar, N.T., 1993. Pollen Grains of New Zealand Dicotyledonous Plants. Maanaki Whenua Press, Lincoln, New Zealand, pp. 200.

Moar, N.T., Suggate, R.P., Burrows, C., 2008. Environments during the Kaihinu Interglacial and Otira glaciation, coastal North Westland, New Zealand. New Zealand Journal of Botany 46, 49-63.

Moore, P.D., Webb, J.A., Collinson, M.E., 1991. Pollen Analysis, second ed. Blackwell Scientific Publications, London, pp. 216.

Nelson, C.S., Cooke, P.J., Hendy, C.H., Cuthbertson, A.M., 1993. Oceanographic and climatic changes over the past 160,000 years at deep sea drilling project site 594 off southeastern New Zealand, Southwest Pacific Ocean. Paleoceanography $8,435-458$.

New Zealand National Climate Centre, 2010. The National Climate Database (online). Available from: http://cliflo.niwa.co.nz/ (accessed 02.02.10.).

Newnham, R.M., Vandergoes, M.J., Hendy, C.H., Lowe, D.J., Preusser, F., 2007a. A terrestrial palynological record for the last two Glacial cycles from southwestern New Zealand. Quaternary Science Reviews 26, 517-535.

Newnham, R.M., Lowe, D.J., Giles, T., Alloway, B.V., 2007b. Vegetation and climate of Auckland, New Zealand, since ca. $32000 \mathrm{cal}$. yr ago: support for an extended LGM. Journal of Quaternary Science 22, 517-534.

Newnham, R.M., McGlone, M.S., Moar, N.T., Wilmshurst, J.M., Vandergoes, M.J., 2013. The vegetation cover of New Zealand at the Last Glacial Maximum. Quaternary Science Reviews 74, 202-214.

Norton, D.A., 1985. A multivariate technique for estimating New Zealand temperature normals. Weather and Climate 5, 64-74

Pelejero, C., Calvo, E., Barrows, T.T., Logan, G.A., De Deckker, P., 2006. South Tasman Sea alkenone paleothermometry over the last four Glacial/Interglacial cycles. Marine Geology 230, 73-86.

Petit, J.R., Jouzel, J., Raynaud, D., Barkov, N.I., Basile, I., Bender, M., Chappellaz, J., Davies, M., Delay, G., 1999. Climate and atmospheric history of the past 420,000 years from the Vostock ice core, Antarctica. Nature 399, 29-436.

Piperno, D.R., 1988. Phytolith Analysis. An Archeological and Geological Perspective. Academic Press, San Diego.

Pocknall, D.T., 1981. Pollen morphology of Phyllocladus L C. et A. Rich. New Zealand Journal of Botany 19, 259-266.

Poole, A.L., Adam, N.M., 1964. Trees and Shrubs of New Zealand. Government Printer, Wellington, pp. 256.

Porter, S.C., 1975. Equilibrium-line altitudes of late Quaternary glaciers in the Southern Alps, New Zealand. Quaternary Research 5, 27-47. 
Prebble, M., Shulmeister, J., 2002. An analysis of phytolith assemblages for the quantitative reconstruction of late Quaternary environments of the lower Taier plain, Otago, South Island, New Zealand II. Paleoenvironmental reconstruction. Journal of Paleolimnology 27, 415-427.

Provan, J., Bennett, K.D., 2008. Phylogeographic insights into cryptic refugia. Trends in Ecology and Evolution 23, 564-571.

Reimer, P.J., Baillie, M.G.L., Bard, E., Bayliss, A., Beck, J.W., Blackwell, P.G., Bronk Ramsey, C., Buck, C.E., Burr, G.S., Edwards, R.L., Friedrich, M., Grootes, P.M., Guilderson, T.P., Hajdas, I., Heaton, T.J., Hogg, A.G., Hughen, K.A., Kaiser, K.F., Kromer, B., McCormac, F.G., Manning, S.W., Reimer, R.W., Richards, D.A., Southon, J.R., Talamo, S., Turney, C.S.M., van der Plicht, J., Weyhenmeyer, C.E., 2009. IntCal09 and Marine09 radiocarbon age calibration curves, $0-50,000$ years cal. BP. Radiocarbon 51, 1111-1150.

Ramsey, C.B., 2009. Dealing with outliers and offsets in radiocarbon dating. Radiocarbon $51,3$.

Shulmeister, J., Soons, J.M., Berger, G.W., Harper, M., Holt, S., Moar Carter, N.J., 1999. Environmental and sea level changes on Banks Peninsula (Canterbury, New Zealand) through three glaciation-interglaciation cycles. Palaeogeography, Palaeoclimatology, Palaeoecology 152, 101-127.

Shulmeister, J., Fink, D., Augustinus, P.C., 2005. A cosmogenic nuclide chronology of the Last Glacial transition in North-West Nelson, New Zealand - new insights in Southern Hemisphere climate forcing during the last deglaciation. Earth and Planetary Science Letters 233, 455-466.

Soons, J.M., 1979. Late Quaternary environments in the central South Island of New Zealand. New Zealand Geographer 35, 16-23.

Stewart, J.R., Lister, A.M., 2001. Cryptic northern refugia and the origins of the modern biota. Trends in Ecology and Evolution 16, 608-613.

Suggate, R.P., 1965. Late Pleistocene Geology of the Northern Part of the South Island, New Zealand. In: New Zealand Geological Survey Bulletin (New Series), vol. 77. New Zealand Department of Scientific and Industrial Research, Wellington, pp. 90.

Suggate, R.P., 1988. Quaternary Deposition and Deformation in the Buller and Tributary Valleys. In: New Zealand Geological Survey Record, vol. 25. Department of Scientific and Industrial Research, Lower Hutt, pp. 51.
Suggate, R.P., Almond, P.C., 2005. The Last Glacial Maximum (LGM) in western South Island, New Zealand: implications for the global LGM and MIS 2. Quaternary Science Reviews 24, 1923-1940.

Sutherland, R., Kim, K., Zondervan, A., McSaveney, M., 2007. Orbital forcing of mid-latitude Southern Hemisphere glaciations since $100 \mathrm{ka}$ inferred from cosmogenic nuclide ages of moraine boulders from the Cascade Plateau, southwest New Zealand. Geological Society of America Bulletin 119 $443-451$.

Thorn, V.C., 2004a. Phytoliths from subantarctic Cambell Island: plant production and soil surface spectra. Review of Paleobotany and Palynology 132, 37-59.

Thorn, V.C., 2004b. An Annotated Bibliography of Phytolith Analysis and Atlas of Selected New Zealand Subalpine Phytoliths. In: Antarctic Data Series, vol. 29. Antarctic Research Centre, Victoria University of Wellington.

Underwood, J., 2006. Soil Phytolith Assemblages Beneath a Nothofagus Treeline Ecotone as a Basis for Treeline Reconstruction. Unpublished honours dissertation thesis, Lincoln University, Canterbury, New Zealand.

Vandergoes, M.J., Newnham, R.M., Preusser, F., Hendy, C.H., Lowell, T.V. Fitsimons, S.J., Hogg, A.G., Kasper, A.U., Schlüchter, C., 2005. Regional insolation forcing of late Quaternary climate change in the Southern Hemisphere. Nature 436, 242-245.

Vandergoes, M.J., Hogg, A.G., Lowe, D.J., Newnham, R.M., Denton, G.H., Southon, J., Barrell, D.J.A., Wilson, C.J.N., McGlone, M.S., Allan, A.S.R., Almond, P.C., Petchy, F. Dabell, K., Dieffenbacher-Krall, A.C., Blaauw, M., 2013. A revised age for the Kawawkawa/Oruanui tephra, a key marker for the Last Glacial Maximum in New Zealand. Quaternary Science Reviews 74, 195-201.

Wardle, P., 1965. A comparison of alpine timber lines in New Zealand and North America. New Zealand Journal of Botany 3, 113-135.

Wardle, P., 1980. Primary succession in Westland National Park and its vicinity, New Zealand. New Zealand Journal of Botany 18, 221-232.

Wilmshurst, J.M., McGlone, M.S., Leathwick, J.R., Newnham, R.M., 2007. A predeforestation pollen-climate calibration model for New Zealand and quantitative temperature reconstructions for the past 18000 years BP. Journal of Quaternary Science 22, 535-547. 